\title{
Water-Vapor Measurements of Low-Slope Roofing Materials
}

Douglas M. Burch

Andre O. Desjarlais

July 1995

Building and Fire Research Laboratory

National Institute of Standards and Technology

Gaithersburg, MD 20899

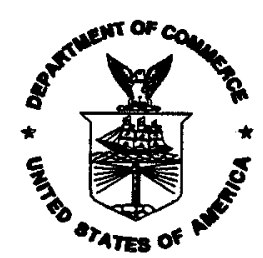

U.S. Department of Commerce

Ronald H. Brown, Secretary

Technology Administration

Mary L. Good, Under Secretary for Technology

National Institute of Standards and Technology

Arati Prabhakar, Director
Prepared for:

Oak Ridge National Laboratory

Oak Ridge, TN 


\section{TABLE OF CONTENTS}

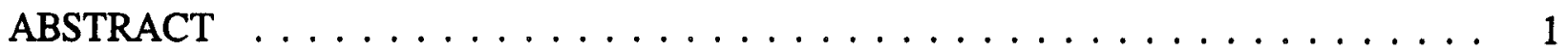

KEY WORDS $\ldots \ldots \ldots \ldots \ldots \ldots \ldots$

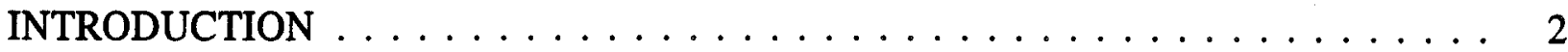

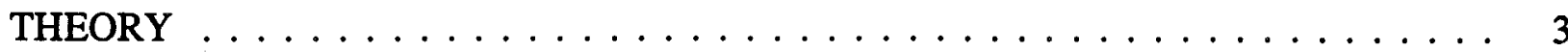

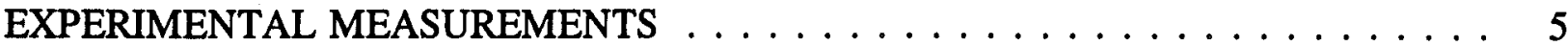

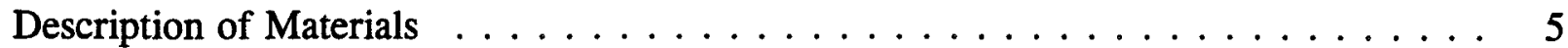

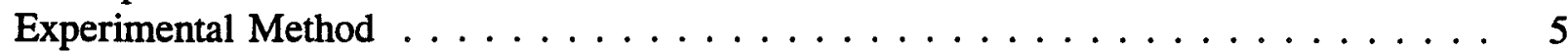

Sorption Isotherm Measurements $\ldots \ldots \ldots \ldots \ldots \ldots$

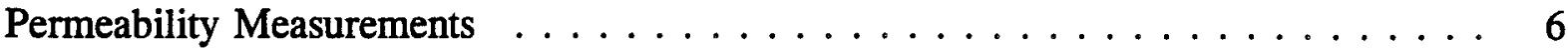

Discussion of Results $\ldots \ldots \ldots \ldots \ldots$

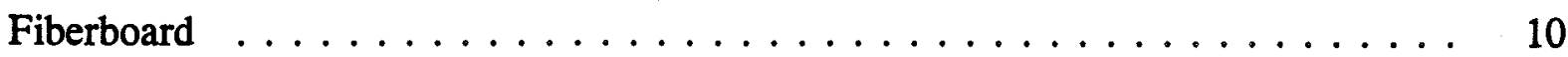

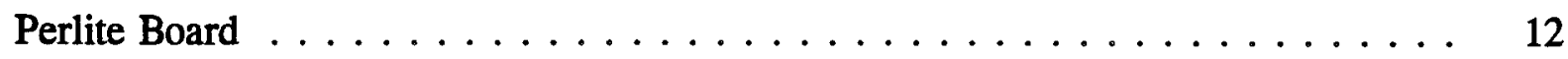

Exterior-Grade Plywood $\ldots \ldots \ldots \ldots \ldots \ldots$

Polyisocyanurate Board with Glass-Matt Facers . . . . . . . . . . . . . . 15

Glass-Fiber Board Insulation with Facer . . . . . . . . . . . . . . . 15

Comparison of Properties for Materials . . . . . . . . . . . . . . . . . 19

UNCERTAINTY OF MEASUREMENTS $\ldots \ldots \ldots \ldots \ldots \ldots \ldots \ldots$

Sorption Isotherm Measurements . . . . . . . . . . . . . . . . . . . . 22

Permeability Measurements . . . . . . . . . . . . . . . . . . . 22

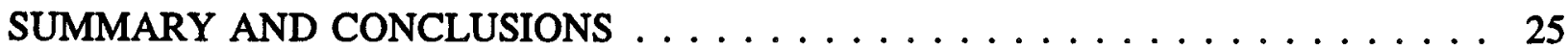

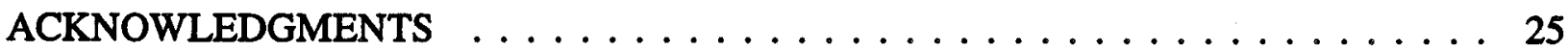

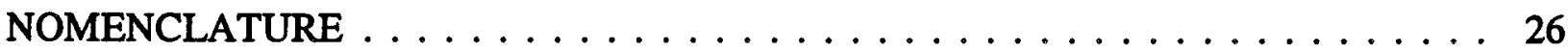

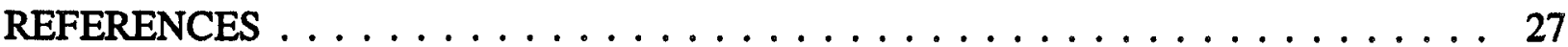




\section{LIST OF FIGURES}

Figure 1 The sorption isotherm $\ldots \ldots \ldots \ldots \ldots \ldots \ldots$

Figure 2 Schematic of conditioning jar $\ldots \ldots \ldots \ldots \ldots \ldots$

Figure 3 Schematic illustrating experimental method $\ldots \ldots \ldots \ldots$

Figure 4 Water-vapor properties of fiberboard

a. Sorption isotherm

b. Permeability $\ldots \ldots \ldots \ldots \ldots \ldots \ldots \ldots \ldots \ldots$

Figure 5 Water-vapor properties of perlite board

a. Sorption isotherm

b. Permeability $\ldots \ldots \ldots \ldots \ldots \ldots \ldots \ldots \ldots \ldots$

Figure 6 Water-vapor properties of exterior-grade plywood

a. Sorption isotherm

b. Permeability $\ldots \ldots \ldots \ldots \ldots \ldots \ldots \ldots \ldots \ldots$

Figure 7 Water-vapor properties of insulation for polyisocyanurate board

a. Sorption isotherm

b. Permeability $\ldots \ldots \ldots \ldots \ldots \ldots \ldots \ldots \ldots \ldots$

Figure 8 Water-vapor properties of facers for polyisocyanurate board

a. Sorption isotherm

b. Permeability

Figure 9 Water-vapor properties of insulation for glass-fiber board

a. Sorption isotherm

b. Permeability

Figure 10 Water-vapor properties of facer for glass-fiber board

a. Sorption isotherm

b. Permeability

Figure 11 Comparison of water-vapor properties for roofing materials

a. Sorption isotherm

b. Permeability

Figure 12 Plot of uncertainty of permeability measurement versus specimen

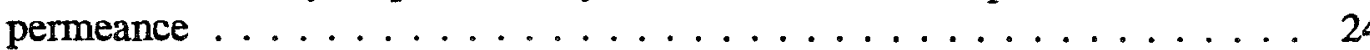




\section{LIST OF TABLES}

Table $1 \quad$ Specification of Materials $\ldots \ldots \ldots \ldots \ldots \ldots \ldots \ldots$

Table 2 Equilibrium Relative Humidities for Saturated Salt Solutions (from Greenspan at $\left.25^{\circ} \mathrm{C}\left(77^{\circ} \mathrm{F}\right)\right) \ldots \ldots \ldots \ldots \ldots$

Table 3 Relative Humidities of Saturated Salt-in-Water Solutions (Temperature of $\left.24^{\circ} \mathrm{C}\left(75^{\circ} \mathrm{F}\right)\right) \ldots \ldots \ldots \ldots \ldots$

Table 4 Water-Vapor Transfer Resistance of Two Air Layers . . . . . . . . . . 10

Table 5 Uncertainty of Permeability Measurements $\ldots \ldots \ldots \ldots$ 


\begin{abstract}
New measurement methods recently developed at the National Institute of Standards and Technology were used to measure the sorption isotherm and permeability of several low-slope roofing materials at a mean temperature of $24^{\circ} \mathrm{C}\left(75^{\circ} \mathrm{F}\right)$. The materials included: fiberboard, perlite board, exterior-grade plywood, polyisocyanurate board insulation with glass-matt facers, and glass-fiber board insulation with a facer.

For the sorption isotherm measurements, the materials were placed in various ambient relative humidities ranging from a dry to a saturated state. The equilibrium moisture content plotted versus ambient relative humidity at $24^{\circ} \mathrm{C}\left(75^{\circ} \mathrm{F}\right)$ gave the sorption isotherm. Separate sorption isotherms were obtained for specimens initially dry (adsorption isotherm) and specimens initially saturated (desorption isotherm).

For the permeability measurements, a series of cup measurements was performed, and the permeability was plotted as a function of the mean relative humidity across the specimen.

The measurements revealed that the moisture properties of building materials are often significantly dependent on average relative humidity. Standard measurement methods currently in use in the United States do not adequately account for the effect of relative humidity on moisture properties.
\end{abstract}

\title{
KEY WORDS
}

moisture, moisture transfer, sorption isotherm, water-vapor permeability, water-vapor transfer, and moisture property. 


\section{INTRODUCTION}

The re-covering of roofs is a widely practiced form of re-roofing that is becoming increasingly popular. One of the main reasons for re-roofing is moisture incursion into the roof system. The decks of original roof systems often have a very high water-vapor transfer resistance. When a roof is re-covered, water entrained in the insulation of the original roof system may become entrapped because the exterior membrane of the re-cover roof is designed to be water (and water vapor) impermeable. A critical issue is whether this entrapped water will lead to premature failure of the re-cover roof system.

Another issue is that entrained moisture causes significant increases in the heat transmission through roof systems. Anderson (1985) conducted an extensive field survey of low-slope roofs and found a significant percentage had high levels of liquid water entrained in the insulation. The primary mechanism of water entry into a low-slope roof is believed to be defects, fractures, and tears in the exterior membrane. Knab, Mathey, and Jenkins (1981) Tobiasson, Greatorex, and Van Pelt (1991) and Hedlin (1988) have shown that moisture can have a profound effect on the heat transmission of roofs.

The Oak Ridge National Laboratory (ORNL) is currently conducting a comprehensive research program to investigate the self-drying potential of wet roofs which are re-covered. The drying rates in several low-slope roofs are being investigated after the inflow of water has been arrested by repairing or recovering the exterior membrane. These roofs dry slowly over time by vapor diffusion downward through the roof deck. Measured drying rates for these roofs will be compared to predicted drying rates using a heat and moisture transfer computer model, called MATCH, developed by Rode (1990). This computer model needs moisture transfer properties for the roofing materials as input in order to make accurate predictions. In support of this research program, ORNL shipped five different roofing materials to NIST for moisture property measurement.

The National Institute of Standards and Technology (NIST) recently has developed a test method (Burch, et al. 1992) to measure the water-vapor permeability of building materials as a function of relative humidity. Standard test methods currently in use (e.g., ASTM Test Method E 96-80 [ASTM 1994]) specify two permeability measurements: a wet cup and a dry cup. The permeability for some materials, however, increases exponentially with relative humidity, and two measurement points are insufficient to characterize their permeability. In addition, NIST has recently developed a test method (Richards, et al. 1992) to measure the relationship between equilibrium moisture content and relative humidity. This relationship is called the "sorption isotherm." Standard test methods are currently unavailable to measure sorption isotherms of materials. 


\section{THEORY}

The transient one-dimensional movement of water vapor within a material is given by the conservation of mass equation:

$$
\frac{\partial}{\partial x}\left[\mu(T, \phi) \frac{\partial}{\partial x}\left(\phi P_{s}(T)\right)\right]=\rho G(T, \phi) \frac{\partial \phi}{\partial t}
$$

where

$\phi=$ relative humidity

$\mathrm{P}_{\mathrm{s}}=$ saturated water-vapor pressure, $\mathrm{Pa}$ (inHg)

$\mathrm{T}=$ temperature, ${ }^{\circ} \mathrm{C}\left({ }^{\circ} \mathrm{F}\right)$

$\mathrm{x}=$ distance, $\mathrm{m}(\mathrm{ft})$

$\mathrm{t}=$ time, and

$\rho=$ dry density of material, $\mathrm{kg} / \mathrm{m}^{3}\left(\mathrm{lb} / \mathrm{ft}^{3}\right)$

Other symbols are defined below. This equation equates the net influx of water-vapor diffusion to the hygroscopic moisture storage.

The property $\mu(T, \phi)$ is called the permeability. Previous water-vapor permeability measurements (Burch, Thomas, and Fanney 1992) have shown that the permeability is a weak function of temperature over the temperature range found in buildings. In the present paper, permeability is assumed to be independent of temperature.

The property $\mathrm{G}(\mathrm{T}, \phi)$, called the specific moisture capacity, is the slope of the sorption isotherm function $\mathrm{f}(\mathrm{T}, \phi)$ given by:

$$
G(T, \phi)=\frac{\partial f(T, \phi)}{\partial \phi} \approx \frac{\partial f(\phi)}{\partial \phi}
$$

The sorption isotherm is a weak function of temperature, and its temperature dependence is neglected in the present study. A typical sorption isotherm is shown in Figure 1. The sorption isotherm function characterizes the storage of moisture within a material. 


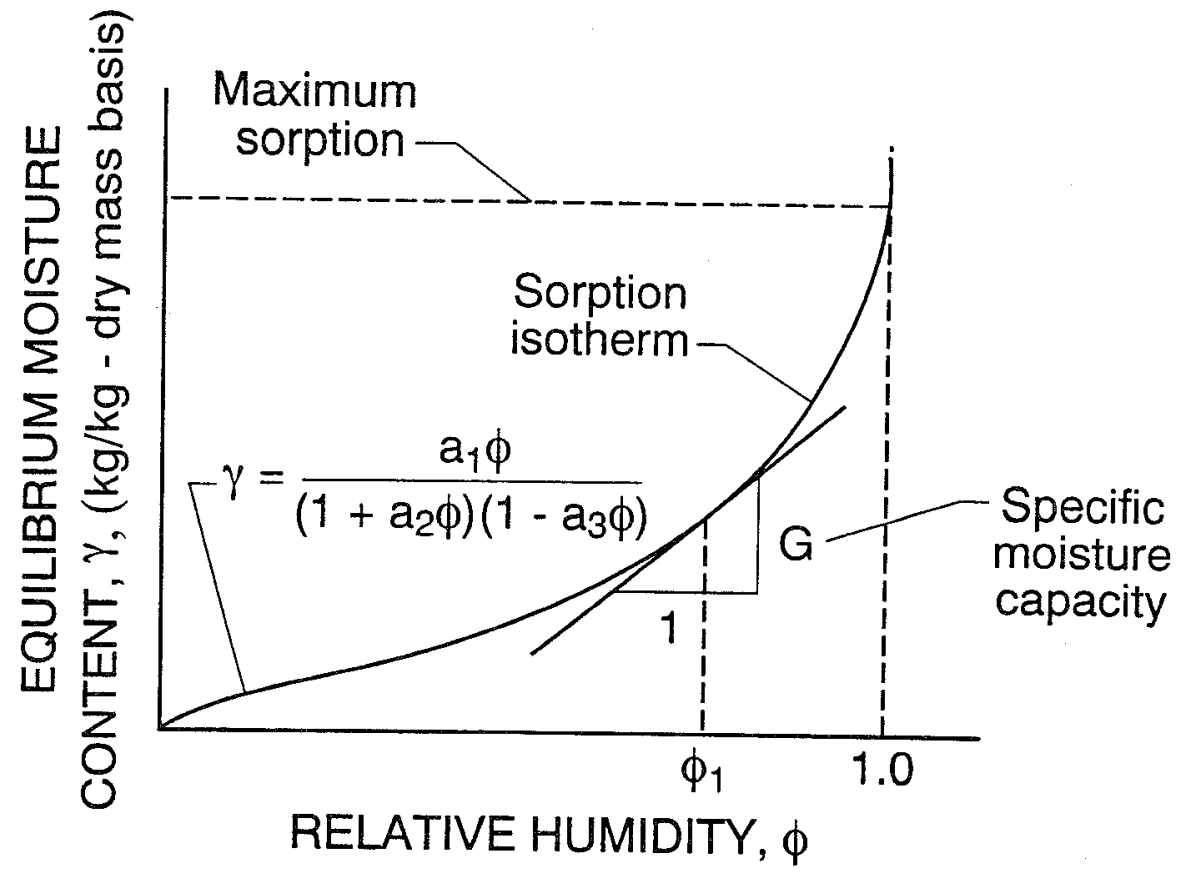

Fig. 1. The sorption isotherm.

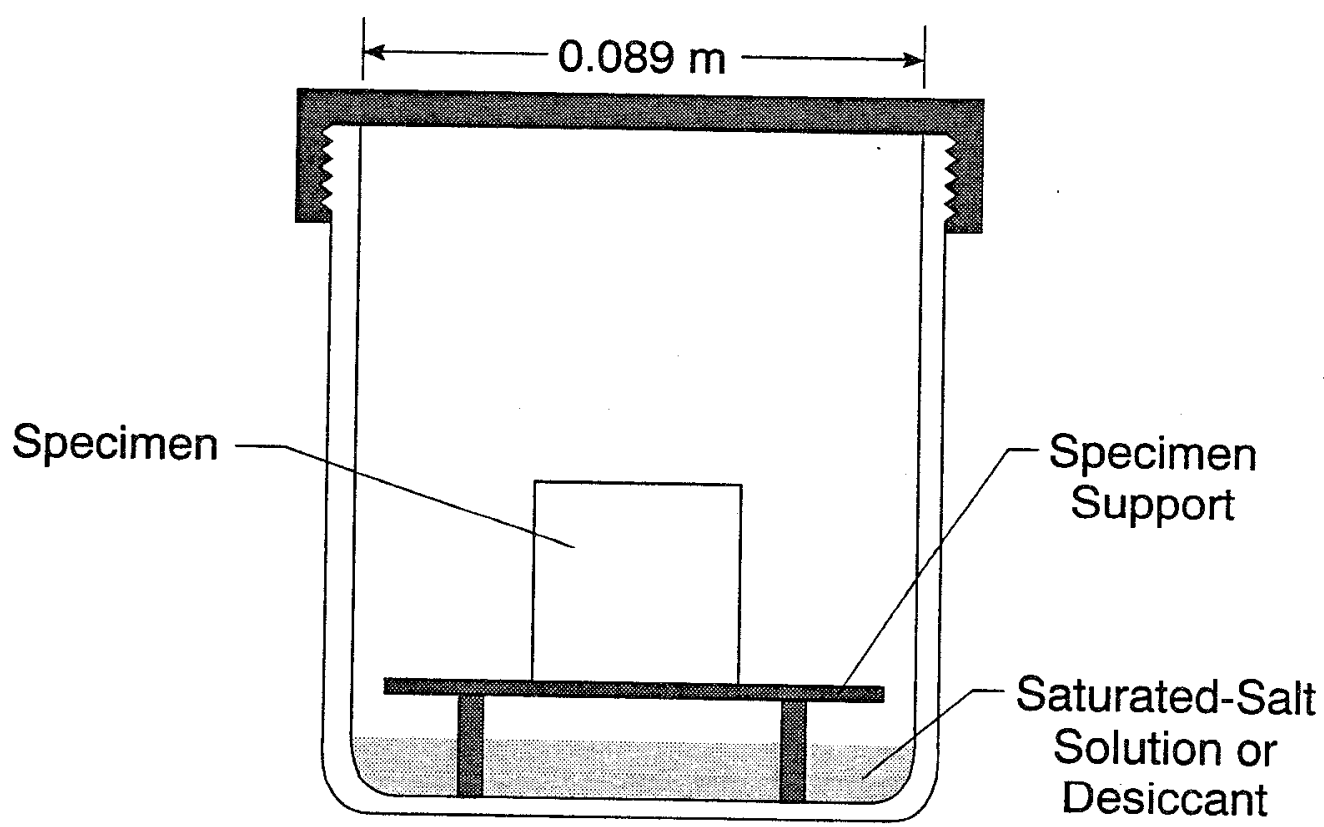

Conditioning Jar

Fig. 2. Schematic of conditioning jar. 


\section{EXPERIMENTAL MEASUREMENTS}

\section{Description of Materials}

The thickness and density of the test materials were measured at NIST and the results are given in Table 1. The polyisocyanurate board and the glass-fiber board contained facers. When an insulation material contained a facer, separate measurements were carried out for the insulation and the facer.

\begin{tabular}{||l|c|c|c|c||}
\hline \hline & \multicolumn{3}{c|}{ Table 1} \\
\hline & Material & Thecification of Materials & \multicolumn{2}{c||}{ Density } \\
\hline & $\mathrm{mm}$ & $\mathrm{in}$ & $\mathrm{kg} / \mathrm{m}^{3}$ & $\mathrm{lb} / \mathrm{ft}^{3}$ \\
\hline \hline Fiberboard & 25.1 & 0.988 & 301 & 18.8 \\
\hline Perlite Board & 25.1 & 0.988 & 173 & 10.8 \\
\hline Exterior-Grade Plywood & 12.1 & 0.477 & 578 & 36.1 \\
\hline Polyisocyanurate Board & & & & \\
Insulation & 24.6 & 0.969 & 32.5 & 2.03 \\
Glass-Matt Facers & 0.819 & 0.0323 & 432 & 26.9 \\
\hline Glass-Fiber Board & & & & \\
Insulation & 23.6 & 0.93 & 122 & 7.6 \\
Facer & 1.64 & .0645 & 882 & 55.1 \\
\hline
\end{tabular}

\section{Experimental Method}

\section{Sorption Isotherm Measurements}

The measurement method presented in this section is based on Richards, et al. (1992). Specimens of each material were desiccated by placing them on a support and sealing them in separate pint-size jars above dry calcium-chloride $\left(\mathrm{CaCl}_{2}\right)$, as shown in Figure 2. The equilibrium relative humidity above this desiccant was taken to be $1.4 \%$ (Baxter and Starkweather 1916). Desiccant drying, as opposed to oven drying, was used to remove moisture, to prevent the removal of other volatiles and minimizing chemical or structural changes in the specimens. The specimens were weighed weekly until no change in specimen mass in consecutive weights indicated that equilibrium with the desiccant had been established. All measurements were made with a precision electronic balance having a resolution of $1 \times 10^{-7}$ $\mathrm{kg}\left(2.2 \times 10^{-7} \mathrm{lb}\right)$. 
Eight of the desiccated specimens were subsequently placed in jars above eight different saturated salt-in-water solutions. The salt solutions provided various ambient relative humidities within the jars ranging from $11.3 \%$ to $97.3 \%$ (see Table 2). The salt solution jars were maintained at a constant laboratory temperature of $24^{\circ} \pm 0.6^{\circ} \mathrm{C}\left(76^{\circ} \pm 1.1^{\circ} \mathrm{F}\right)$. The eight specimens were periodically weighed until equilibrium with the salt solutions was established. The moisture content was determined by taking the difference between the moist and dry masses and dividing by the dry mass. The equilibrium moisture content for the initially dry specimens was plotted as a function of ambient relative humidity to give the "adsorption isotherm."

Another eight specimens were placed above water (i.e., approximately $100 \% \mathrm{rh}$ ) until they reached their maximum sorption moisture content. The eight saturated specimens were subsequently placed inside the jars with the eight salt solutions, and their equilibrium moisture contents were determined. The equilibrium moisture content for the initially saturated specimens was plotted versus ambient relative humidity to give the "desorption isotherm."

\begin{tabular}{|c|c|c|}
\hline \multicolumn{3}{|c|}{$\begin{array}{l}\text { Table } 2 \\
\text { Equilibrium Relative Humidities for Saturated Salt Solutions } \\
\text { (from Greenspan at } 25^{\circ} \mathrm{C}\left(77^{\circ} \mathrm{F}\right) \text { ) }\end{array}$} \\
\hline Salt & Formula & Equilibrium rh, \% \\
\hline Lithium Chloride & $\mathrm{LiCl}$ & $11.3 \pm 0.3^{1}$ \\
\hline Magnesium Chloride & $\mathrm{MgCl}_{2} 6 \mathrm{H}_{2} \mathrm{O}$ & $32.8 \pm 0.2^{1}$ \\
\hline Potassium carbonate & $\mathrm{K}_{2} \mathrm{CO}_{3}$ & $43.2 \pm 0.3^{1}$ \\
\hline Sodium bromide & $\mathrm{NaBr}$ & $57.6 \pm 0.4$ \\
\hline Ammonium chloride & $\mathrm{NH}_{4} \mathrm{CL}$ & $78.6 \pm 0.4^{1}$ \\
\hline Potassium chloride & $\mathrm{KCl}$ & $84.3 \pm 0.3^{1}$ \\
\hline Potassium nitrate & $\mathrm{KNO}_{3}$ & $93.6 \pm 0.6^{1}$ \\
\hline Potassium sulfate & $\mathrm{K}_{2} \mathrm{SO}_{4}$ & $97.3 \pm 0.5^{1}$ \\
\hline
\end{tabular}

\section{Permeability Measurements}

The measurement method described in this section is based on Burch, et al. (1992). Five specimens for each of the 7 materials were installed and sealed with wax at the top of glass permeability cups. The specimens were $140 \mathrm{~mm}(5.5 \mathrm{in}$.) in diameter. The permeability cups were placed inside sealed glass vessels as shown in Figure 3. Saturated salt-in-water solutions were used inside the permeability cups and glass vessels to generate different relative humidity 


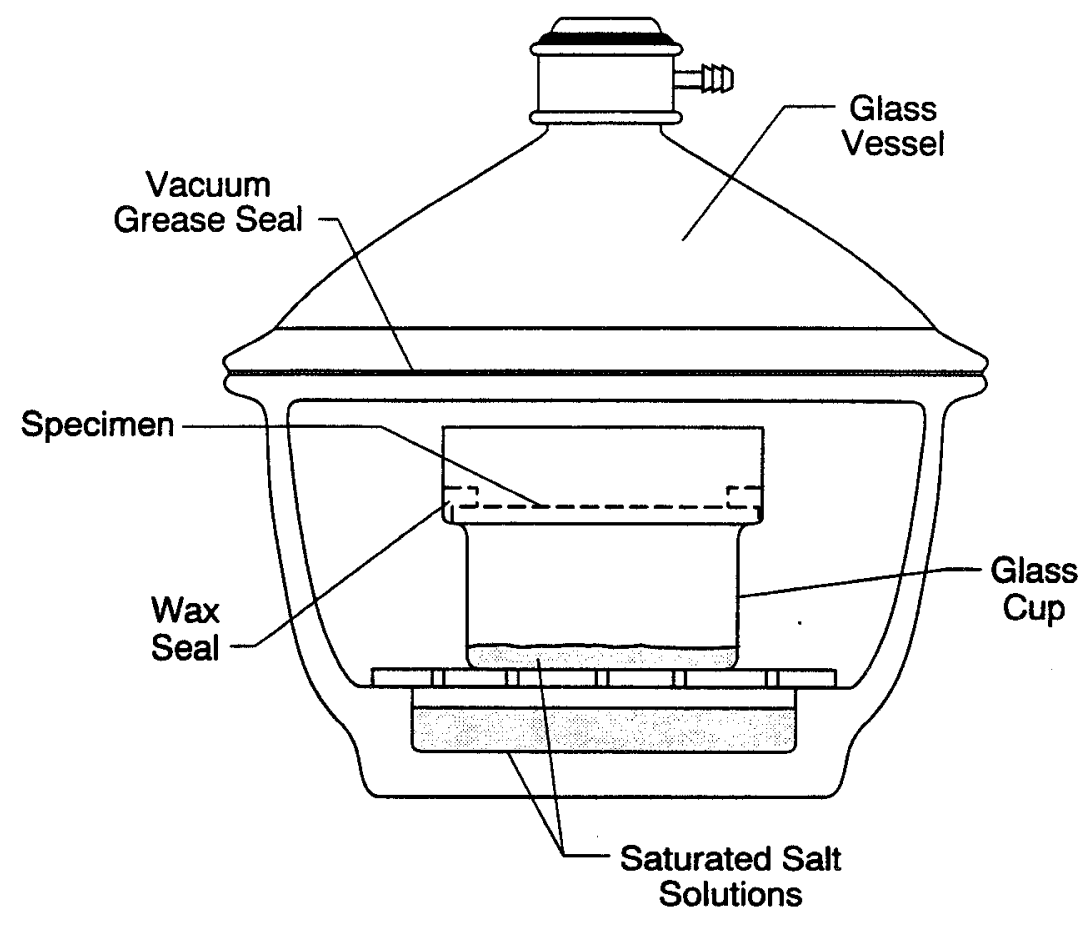

Fig. 3. Schematic illustrating experimental method. 
environments at the lower and upper surfaces of the specimens. The salt solutions given in Table 3 were used to provide differences in relative humidity of about $10 \%$ across the specimens.

\begin{tabular}{|c|c|c|c|c|}
\hline \multirow{3}{*}{$\begin{array}{l}\text { Cup } \\
\text { No. }\end{array}$} & \multicolumn{4}{|c|}{$\begin{array}{l}\text { Table } 3 \\
\text { Relative Humidities of Saturated Salt-in-Water Solutions } \\
\text { (Temperature of } 24^{\circ} \mathrm{C}\left(\mathbf{7 5}^{\circ} \mathrm{F}\right)\end{array}$} \\
\hline & \multicolumn{2}{|c|}{ Cup } & \multicolumn{2}{|c|}{ Vessel } \\
\hline & Salt & rh, $\%$ & Salt & rh, \% \\
\hline 1 & $\mathrm{LCl}$ & $11.30 \pm 0.27$ & $\mathrm{KC}_{2} \mathrm{H}_{3} \mathrm{O}_{2}$ & $22.67 \pm 0.32$ \\
\hline 2 & $\mathrm{MgCl}_{2}$ & $32.85 \pm 0.16$ & $\mathrm{~K}_{2} \mathrm{CO}_{3}$ & $43.16 \pm 0.39$ \\
\hline 3 & $\mathrm{NaBr}$ & $57.92 \pm 0.40$ & $\mathrm{KI}$ & $69.09 \pm 0.24$ \\
\hline 4 & $\mathrm{NaCl}$ & $75.33 \pm 0.12$ & $\mathrm{KCl}$ & $84.31 \pm 0.26$ \\
\hline 5 & $\mathrm{Sr}\left(\mathrm{NO}_{3}\right)_{2}$ & $85.46 \pm 0.38$ & $\mathrm{~K}_{2} \mathrm{SO}_{4}$ & $97.36 \pm 0.45$ \\
\hline \multicolumn{5}{|c|}{$\begin{array}{l}2 \text { Equilibrium relative humidities above saturated salt solutions was taken from } \\
\text { Greenspan }(1977) \text {. These relative humidities were also independently verified at } 24^{\circ} \mathrm{C} \\
\left(75^{\circ} \mathrm{C}\right) \text { using a precision dew-point hygrometer having an uncertainty of } \pm 0.2^{\circ} \mathrm{C}( \pm \\
\left.0.4^{\circ} \mathrm{F}\right) \text {. }\end{array}$} \\
\hline
\end{tabular}

Permeability measurements were carried out at $24^{\circ} \mathrm{C}\left(75^{\circ} \mathrm{F}\right)$ by placing the cup/vessel assemblies inside a conditioning chamber that maintained a constant temperature environment within \pm $0.5^{\circ} \mathrm{C}\left( \pm 1^{\circ} \mathrm{F}\right)$.

The water-vapor transfer rate through each specimen was determined by opening the glass vessels, removing the cups, and weighing them once a week. After the cup was put back and the glass vessel lid was sealed again, it took about one hour for the ambient relative humidity inside the glass vessel to return to its equilibrium value. The cup weights were plotted as a function of elapsed time until four weekly measurements were linearly correlated. The watervapor transfer rate (WVT) was computed as the slope of the linear portion of the plot. The permeability $(\mu)$ of each specimen was determined by the relation:

$$
\mu=\frac{\mathrm{L}}{\frac{\mathrm{AP}_{\mathrm{s}}\left(\phi_{\mathrm{u}}-\phi_{\mathrm{P}}\right)}{\mathrm{WVT}}-\mathrm{R}_{\mathrm{f}}}
$$

where $\phi_{\mathrm{u}}$ and $\phi_{1}$ are the equilibrium relative humidities of the saturated salt solutions at the upper and lower surface of the specimen, respectively. The symbol $A$ is the surface area of the specimen, $\mathbf{R}_{\mathrm{f}}$ denotes the water-vapor transfer resistance of the two air layers at the upper and 
lower surfaces of the specimen, and $\mathrm{L}$ is the thickness of the specimen.

When moisture passes through a specimen during a permeability cup test, the relative humidity decreases across the air layers. In very permeable specimens, the magnitude of the water vapor resistance of the material itself [first denominator term of Equation (3)] approaches the magnitude of the air layer resistance $\left(R_{f}\right)$. In this situation, small errors in the air layer resistance propagate into a significant error in the permeability. An uncertainty analysis is presented later in the report. Therefore, it is very important to accurately determine the air layer resistance. Separate measurements described below were conducted to determine the resistance of the two air layers.

Fanney et al. (1991) previously measured the water-vapor transfer resistance of the two air layers for the cup/vessel assemblies. For these measurements, saturated-salt solutions as specified in Table 3 were prepared in the five cups and glass vessels. Low permeability plastic covers were placed over the cups, and they were put inside their respective glass vessels. After the relative humidities above the salt solutions reached equilibrium, the cups were quickly removed from the glass vessels, the plastic covers were removed, and the cups were weighed. The cups were placed back in the glass vessels without the plastic covers. After a one-week period, the cups were again removed and weighed. The water vapor transfer rate (WVT) was determined by taking the difference between the final and initial cup weights and dividing by the elapsed time. For each cup/vessel assembly, the resistance of the two air layers $\left(\mathbf{R}_{f}\right)$ was computed by the relation:

$$
\mathbf{R}_{f}=\frac{\operatorname{AP}_{s}\left(\phi_{u}-\phi_{1}\right)}{W V T}
$$

A concern regarding the above air layer measurements was that a small amount of natural convection between the different humidity environments could have influenced the results. When a specimen is mounted in the cup/vessel assembly, convection between the two humidity environments is eliminated.

To allay this concern, another series of experiments were conducted to again measured the air layer resistances. For these measurements, two sets of five cup/vessel assemblies were prepared consistent with Table 3. In the first set, a single layer of an air infiltration retarder was installed as a specimen in each of the cups. In the second set, three layers of the same air infiltration retarder were installed in each of the cups. By analyzing the difference in water-vapor transfer resistance between the two sets of measurements, it was possible to determine the water-vapor transfer resistance of both the air infiltration retarder and the two air layers.

The above air layer measurements are compared to the previous measurements by Fanney et al. (1991) in Table 4 below. With the exception Cup No. 5, the air layer measurements are in close agreement. For the permeance cup measurements presented in the next section, we used the air layer measurements from Fanney et al. (1991). 


\begin{tabular}{|c|c|c|c|}
\hline \multicolumn{4}{|c|}{$\begin{array}{cc}\text { Table } 4 \\
\text { Water-Vapor Transfer Resistance of Two Air Layers } \\
\end{array}$} \\
\hline \multirow{2}{*}{$\begin{array}{l}\text { Cu } \\
\text { No }\end{array}$} & \multicolumn{2}{|c|}{$\mathrm{R}_{\mathrm{r}}, 10^{8} \mathrm{Pasm}^{2} / \mathrm{kg}$} & \multirow{2}{*}{$\begin{array}{l}\text { Difference } \\
\%\end{array}$} \\
\hline & Fanney et al. (1991) & Present Study & \\
\hline 1 & 6.57 & 6.44 & 2.0 \\
\hline 2 & 7.14 & 7.30 & -2.2 \\
\hline 3 & 7.22 & 6.87 & 5.1 \\
\hline 4 & 7.38 & 7.71 & -4.3 \\
\hline 5 & 6.19 & 9.03 & -31.5 \\
\hline \multicolumn{4}{|c|}{$\begin{array}{ll}\text { Note: } & \mathrm{R}_{\mathrm{f}} \text { can be converted into inHg } \mathrm{ft}^{2} \cdot \mathrm{h} / \text { grain }(1 / \mathrm{perm}) \text { by multiplying by } \\
5.745 \times 10^{-11} \text {. }\end{array}$} \\
\hline
\end{tabular}

\section{Discussion of Results}

\section{Fiberboard}

The equilibrium moisture content of fiberboard is plotted versus ambient relative humidity in Figure 4a. This plotted is called a sorption isotherm. These results indicate that fiber-board is very hygroscopic. As the relative humidity approaches $100 \%$, the moisture content rises to 0.316 or $31.6 \%$.

Data for the adsorption isotherm are depicted with solid circles, and the desorption isotherm with solid squares. The solid curve corresponds to the correlation:

$$
\gamma=\frac{a_{1} \phi}{\left(1+a_{2} \phi\right)\left(1-a_{3} \phi\right)}
$$

where the constants $a_{1}, a_{2}$, and $a_{3}$ have been determined using a least-squares fit of the mean of the adsorption and desorption data at each relative humidity. The form of Equation (5) is based on the activation energy theory for wood (Simpson 1971).

Sorption isotherm measurements by Tveit (1966) for a similar fiberboard material are displayed with open triangles in Figure 4a. For relative humidities below $80 \%$, the measurements of Tveit are $4-5 \%$ moisture content higher than the values of the present study. Possible explanations for the difference are: the fiberboard measured by Tveit had a density of $215 \mathrm{~kg} / \mathrm{m}^{3}(13.4$ $\left.\mathrm{lb} / \mathrm{ft}^{3}\right)$, while the fiberboard of the present study had a density of $301 \mathrm{~kg} / \mathrm{m}^{3}\left(18.8 \mathrm{lb} / \mathrm{ft}^{3}\right)$. Perhaps, more importantly, Tveit used in oven-drying method to determine specimen dry weight, while we used calcium-chloride to desiccate the specimens. Richards, et al. (1992) showed that 


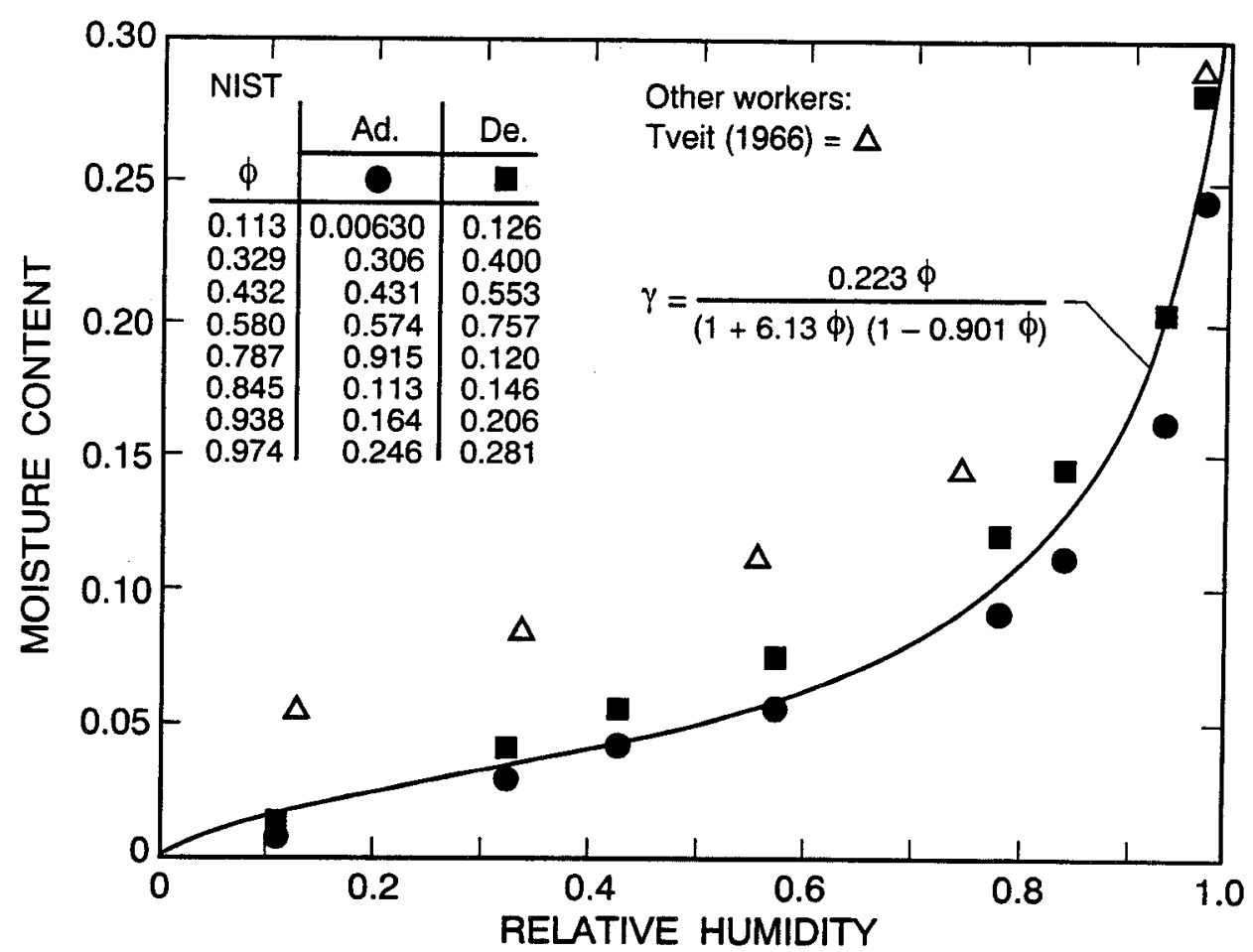

a. Sorption isotherm

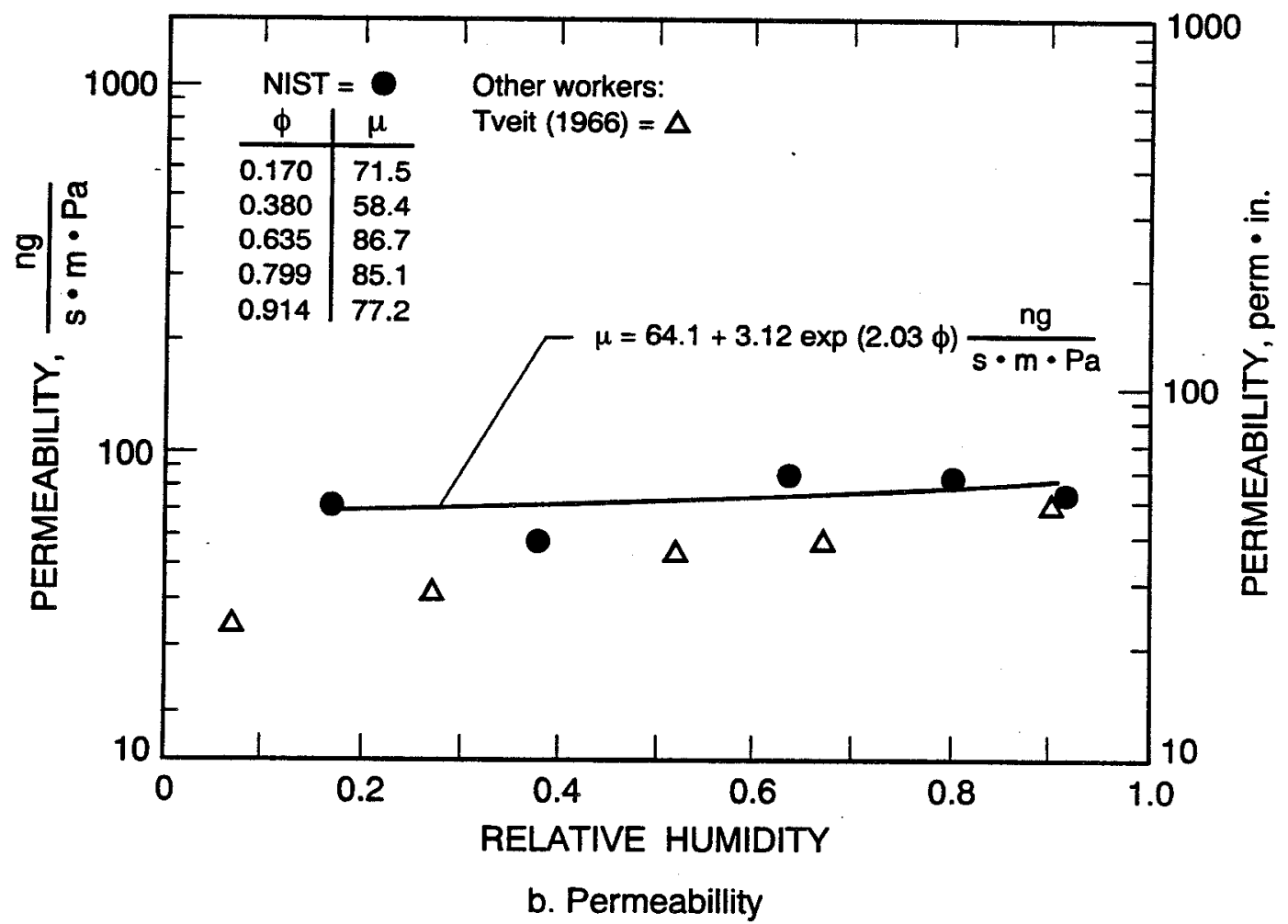

Fig. 4. Water-vapor properties of fiberboard. 
oven drying gives a lower dry weight than desiccant drying. A possible explanation is that oven drying drives off volatiles other than water.

The permeability of fiberboard is plotted versus relative humidity in Figure $4 \mathrm{~b}$. The permeability is seen to be almost constant, although there is a small upward trend with respect to relative humidity. A constant permeability is believed to be a result of a dominance of watervapor diffusion through the large open pore space of the material. The permeability $(\mu)$ was fit to the correlation:

$$
\mu=A_{1}+A_{2} \cdot \operatorname{Exp}\left(A_{3} \cdot \phi\right)
$$

where $A_{1}, A_{2}$, and $A_{3}$ have been selected to minimize the difference between measure and predicted values. The form of Equation (6) is based on Galbraith and McLean (1990).

The permeability measurements of Tveit (1966) are shown with open triangles in Figure $4 \mathrm{~b}$. The agreement between these two different sets of measurements is good, although the measurements of Tveit tend to be lower than those of the present study.

\section{Perlite Board}

The sorption isotherm measurements for perlite board are given in Figure 5a. Perlite board is seen to be less hygroscopic than fiberboard (see Figure 4a).

The permeability measurements for perlite board are given in Figure $5 \mathrm{~b}$. With the exception of the measurement above $90 \%$ rh, the other measurements are correlated by a straight line of constant permeability. The author expected the permeability of perlite board to be a constant because molecular diffusion through a predominately open pore space is the dominant moisture transport mechanism. Since the measurement above $90 \%$ rh departs markedly from the other constant permeability data, it was treated as an outlier.

\section{Exterior-Grade Plywood}

The sorption isotherm measurements for exterior-grade plywood are given in Figure 6a. These results indicate plywood is very hygroscopic as was the case for fiberboard (see Figure 4a). The sorption isotherm for a different plywood material was measured in a previous NIST study (see Burch, et al. 1992) and is shown by the dashed curve given in Figure 6a. Agreement between the previous and present measurements is good.

The permeability measurements for exterior-grade plywood are given in Figure $6 \mathrm{~b}$. In this semi$\log$ plot, the permeability increases markedly with relative humidity. In a dry state (rh less than $60 \%$ ), the plywood has a permeance (permeability divided by thickness) less than $5.7 \times 10^{-11}$ $(1.0$ perm $)$, and therefore functions as a vapor retarder. When the relative humidity approaches a saturated state, the plywood becomes very permeable. From a dry to a moist state, the permeability of this plywood increases by a factor of 30 . 


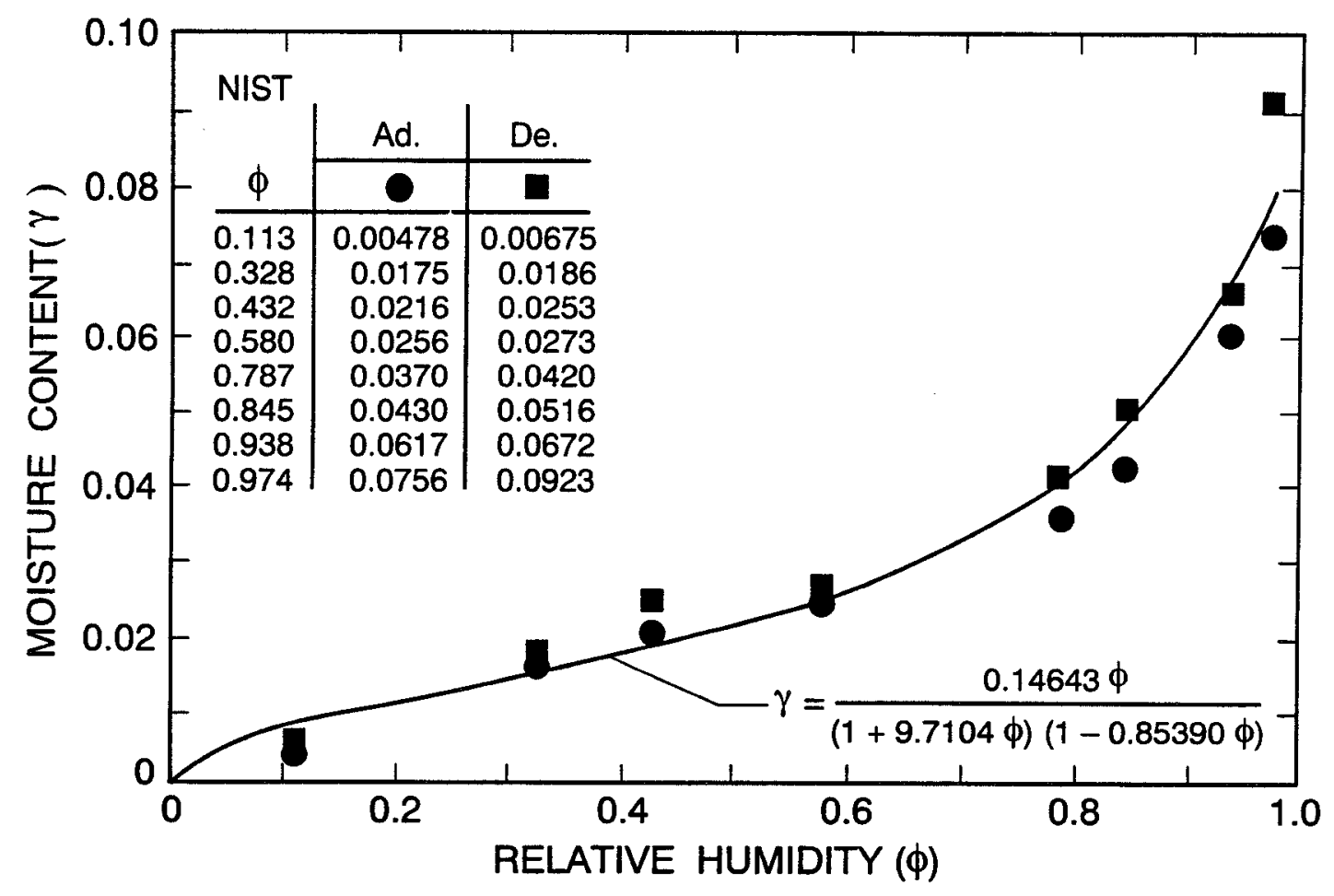

a. Sorption isotherm

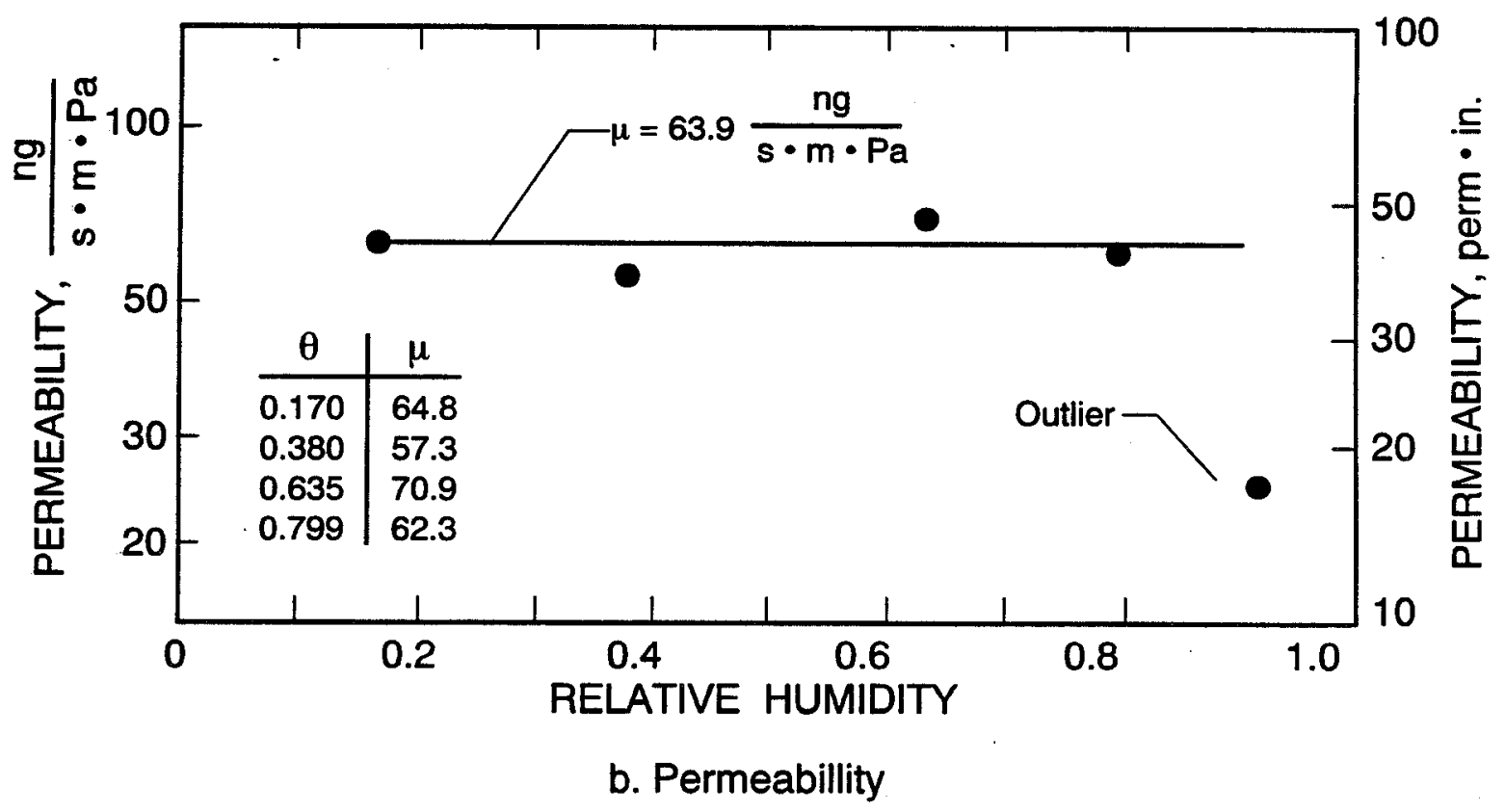

Fig. 5. Water-vapor properties of perlite board. 


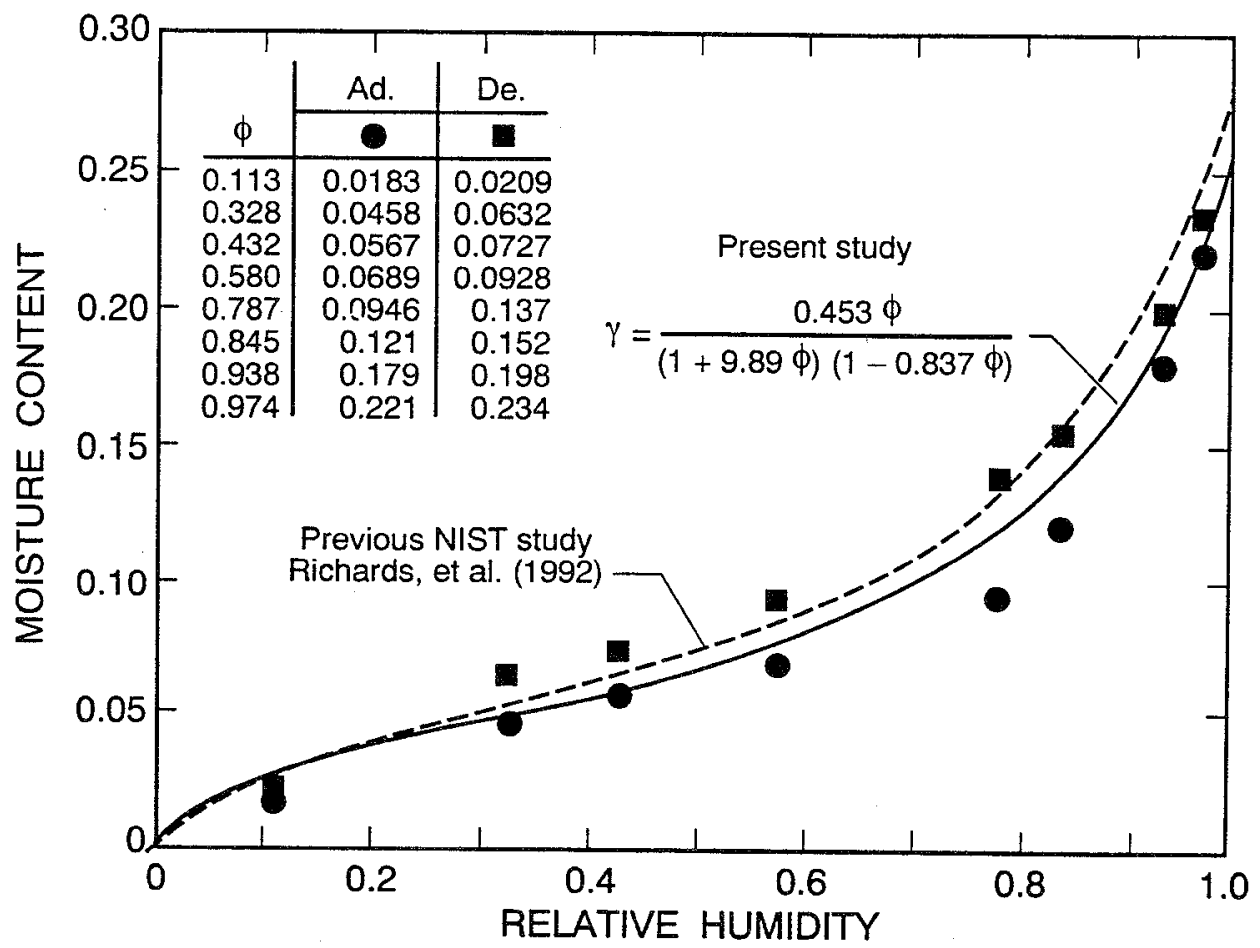

a. Sorption isotherm

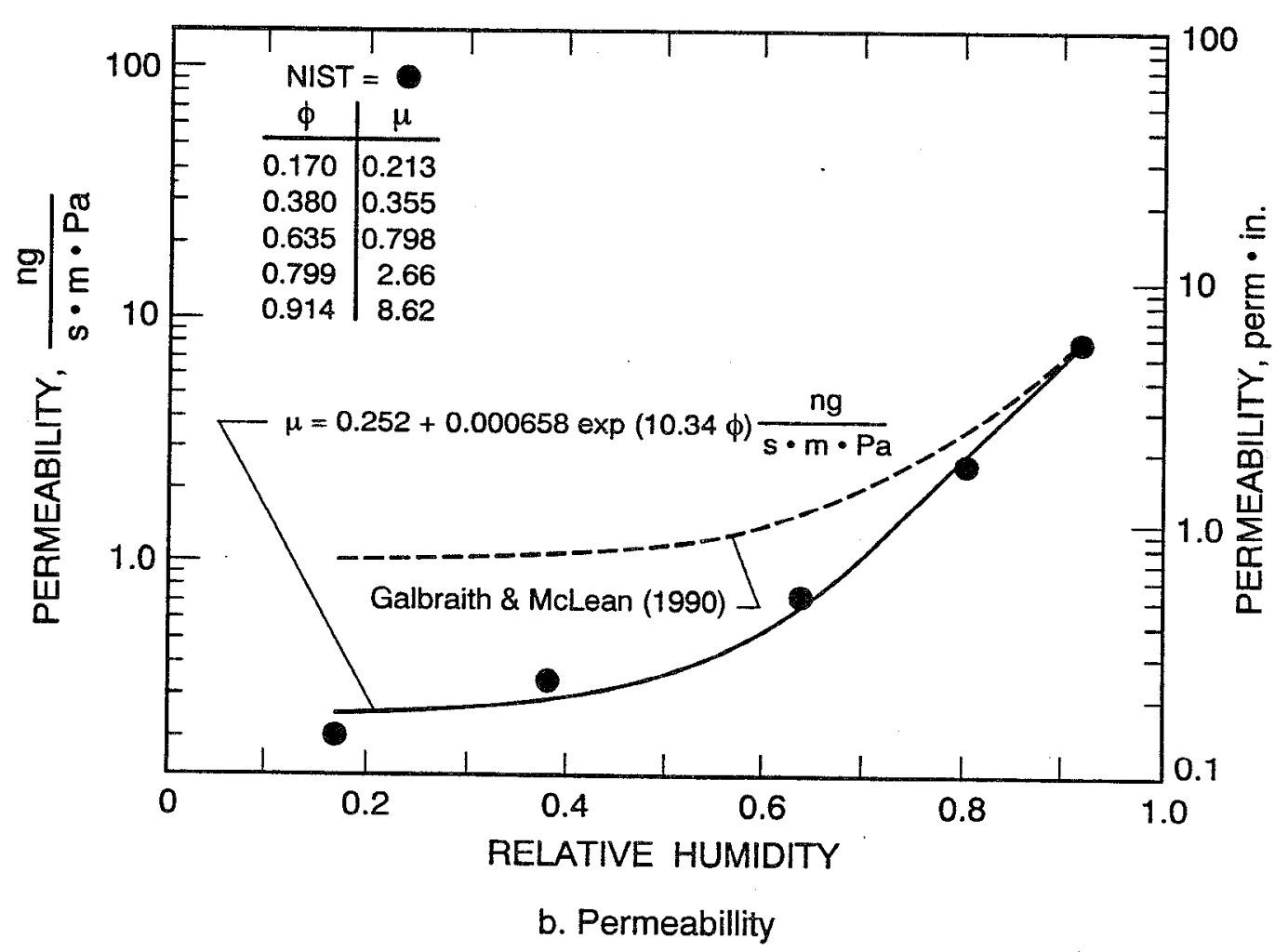

Fig. 6. Water-vapor properties of exterior-grade plywood. 
Previous measurements by Galbraith and McLean (1990) for a different plywood are compared to the present measurements in Figure $6 \mathrm{~b}$. The measurements of the present study are considerably lower than the previous measurements of Galbraith and McLean. Plywood is believed to be a very variable material because different woods and glues are used in the manufacture of plywood.

\section{Polyisocyanurate Board with Glass-Matt Facers}

The sorption isotherm of the insulation for the polyisocyanurate (PIR) board is given in Figure 7a. The PIR insulation is less hygroscopic than fiberboard (see Figure 4a) and exteriorgrade plywood (Figure 6a). To obtain the sorption isotherm, it was necessary to outgas the refrigerant from the insulation in order to stabilize the dry weights of the specimens which continually lost weight due to refrigerant outgasing. Outgasing of the refrigerant was accomplished by exposing the specimens to a constant temperature and relative humidity of $60^{\circ} \mathrm{C}$ $\left(140^{\circ} \mathrm{F}\right)$ and $75 \%$, respectively, for a 2-week period (Nguyen, Byrd, Zarr, Stutzman, and Seiler 1991).

The permeability of the PIR insulation is plotted versus relative humidity in Figure $7 \mathrm{~b}$. For these measurements, it was necessary to install thin slices $[8.2 \mathrm{~mm}(0.32 \mathrm{in})$.$] of the PIR$ insulation in the permeability cups to reduce the time required for the measurements. This is the smallest thickness that could be cut without fracturing the insulation.

The sorption isotherm and permeability measurements of the glass-matt facers for the PIR board are given in Figures $8 \mathrm{a}$ and $8 \mathrm{~b}$, respectively. The faces are seen to be fairly hygroscopic. The permeance (permeability divided by thickness) varies from $600 \mathrm{ng} / \mathrm{s} \mathrm{m}^{2} \cdot \mathrm{Pa}(10$ perm) to 2800 $\mathrm{ng} / \mathrm{s} \mathrm{m}^{2} \cdot \mathrm{Pa}(49 \mathrm{perm})$, indicating that the facers are relatively permeable.

\section{Glass-Fiber Board Insulation with Facer}

The sorption isotherm for insulation for the glass-fiber board is given in Figure 9a. The results indicate that the glass-fiber insulation absorbs very small amounts of water-vapor when placed in a humid ambient environment and therefore is considered to be weakly hygroscopic. The maximum equilibrium moisture content (called maximum sorption) at an ambient relative humidity of $100 \%$ is only 0.023 or $2.3 \%$.

The permeability measurements for glass-fiber insulation are given in Figure $9 \mathrm{~b}$. This material was very difficult to measure because small uncertainty in the water-vapor transfer resistance for the two air layers $\left(R_{f}\right)$ propagate into large uncertainty in the measured permeability ${ }^{1}$. The permeability values for three of the measurements were considered erroneous and treated as outliers. These three measurements were considered to be outliers. Two of the measurements

1 In Equation (3), the term $A \cdot P_{g}\left(\phi_{u}-\phi_{1}\right) / W V T$ approaches the value of $R_{f}$. In this situation, small uncertainty in $R_{f}$ propagates into large uncertainty in permeability $(\mu)$. 


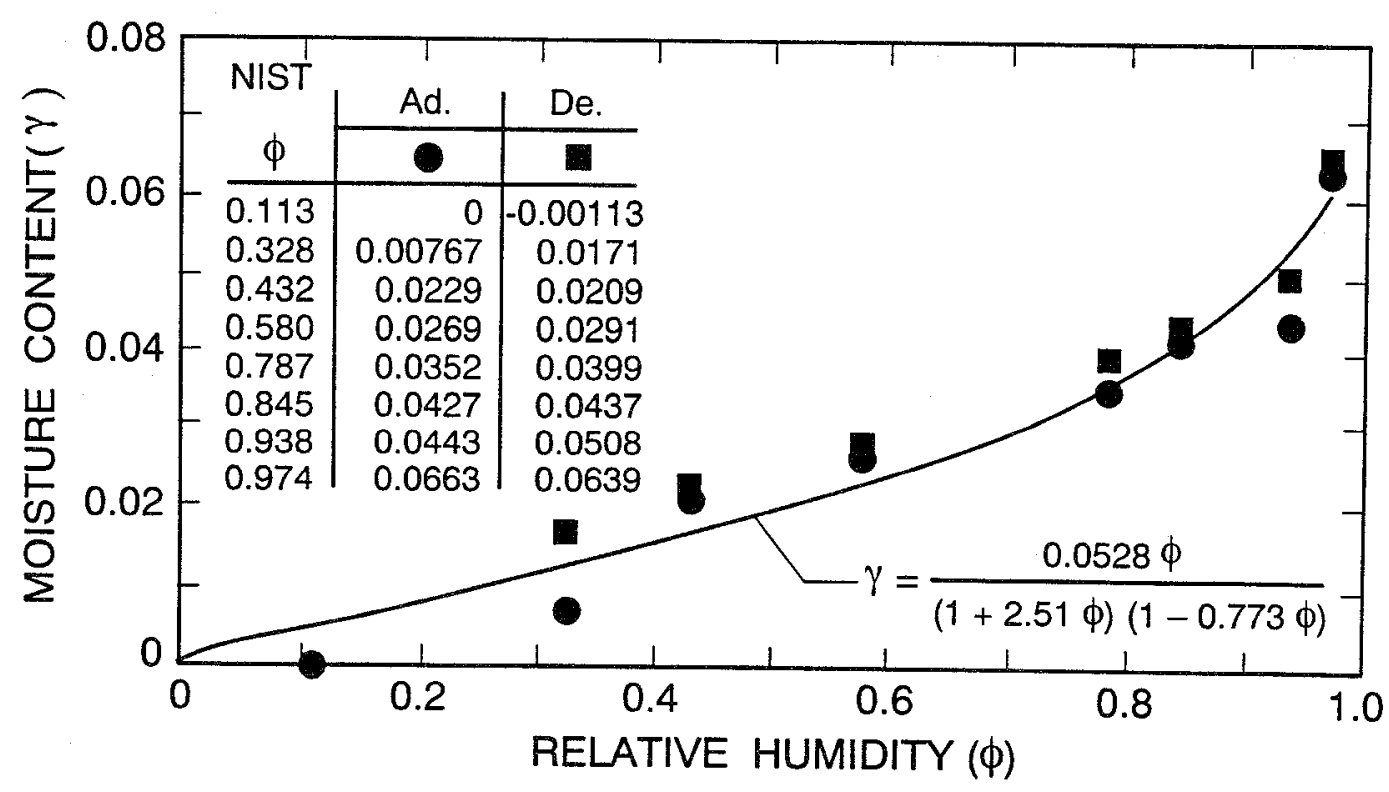

a. Sorption isotherm

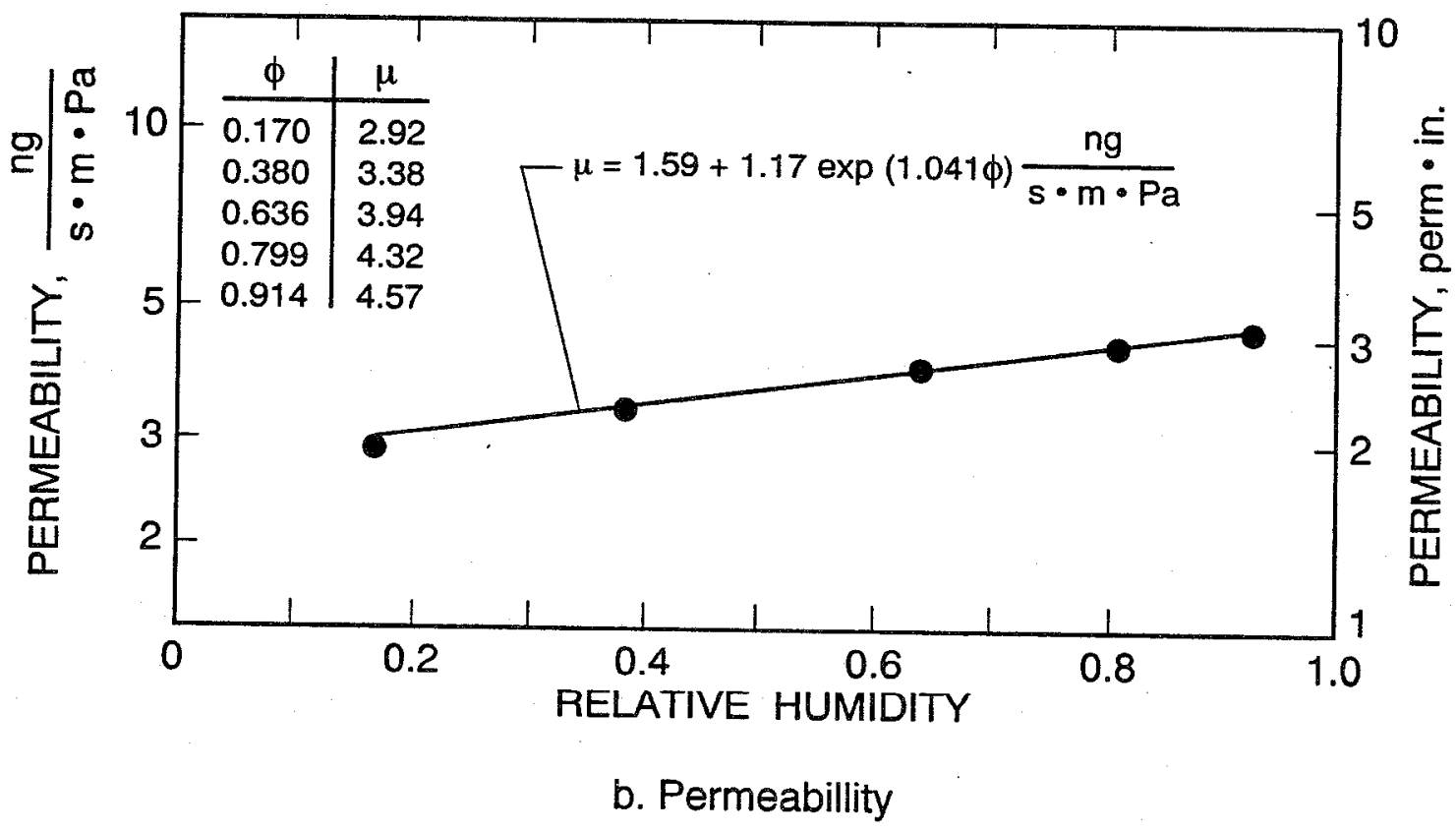

Fig. 7. Water-vapor properties of insulation for polyisocyanurate board. 


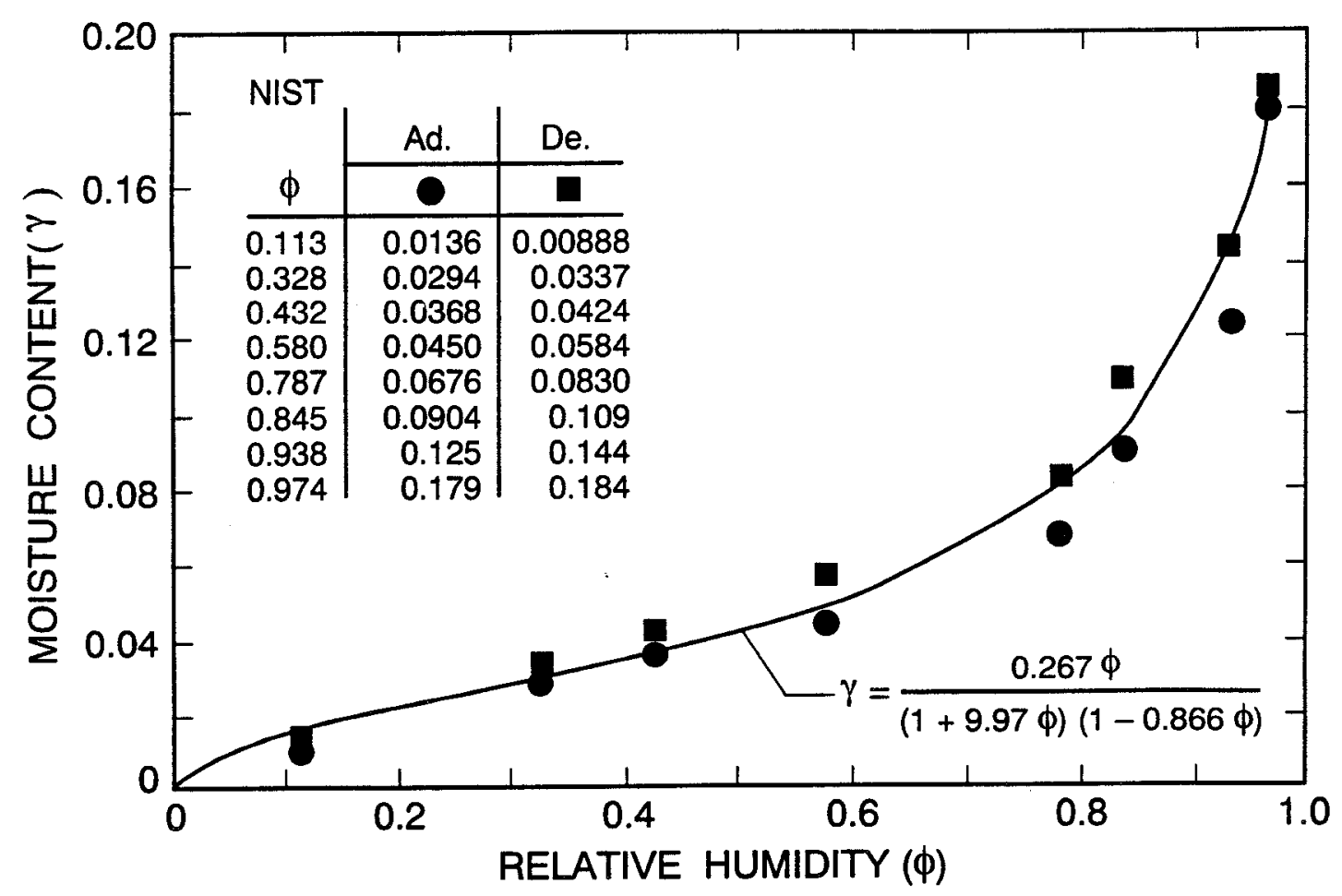

a. Sorption isotherm

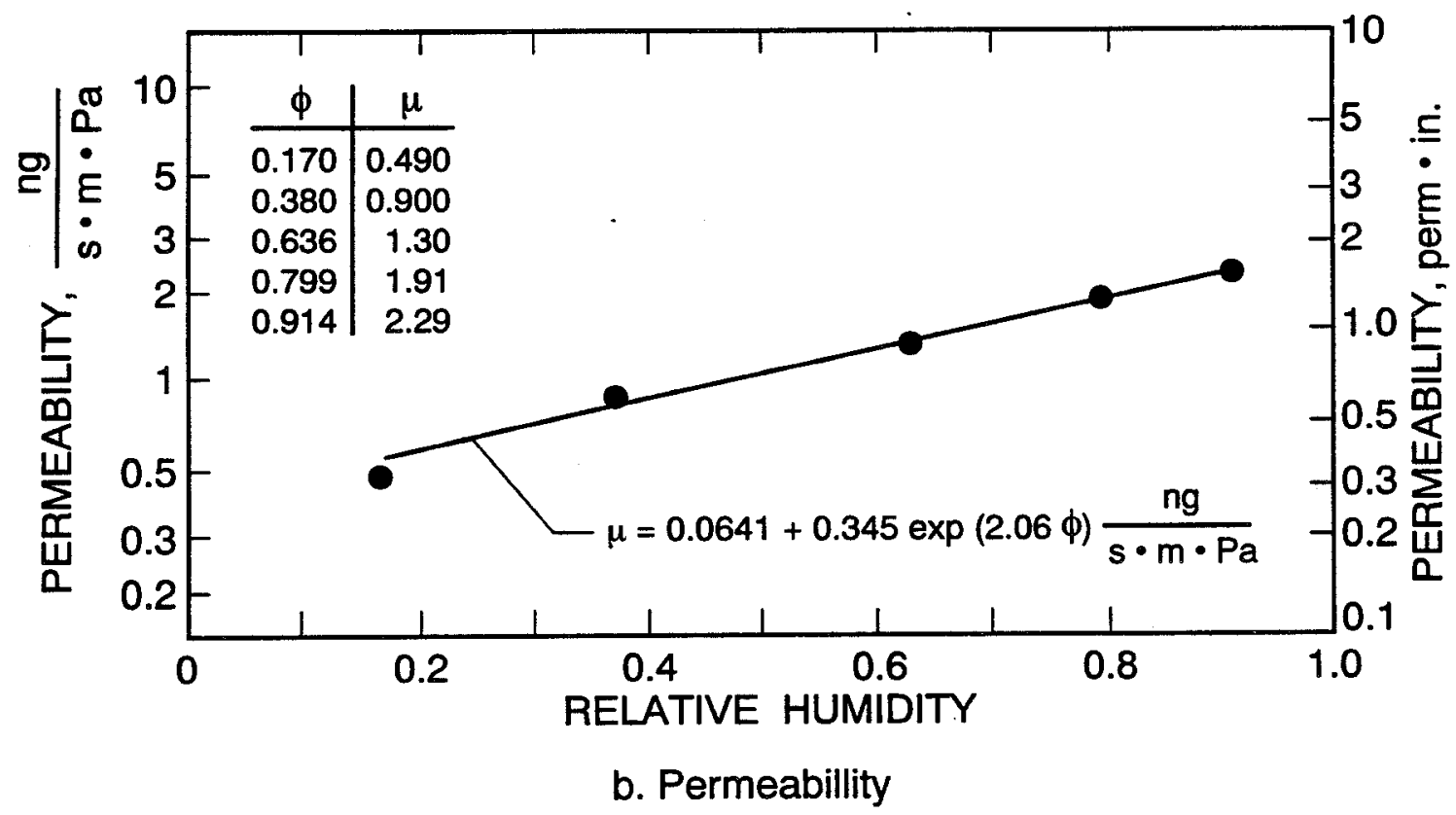

Fig. 8. Water-vapor properties of facers for polyisocyanurate board. 


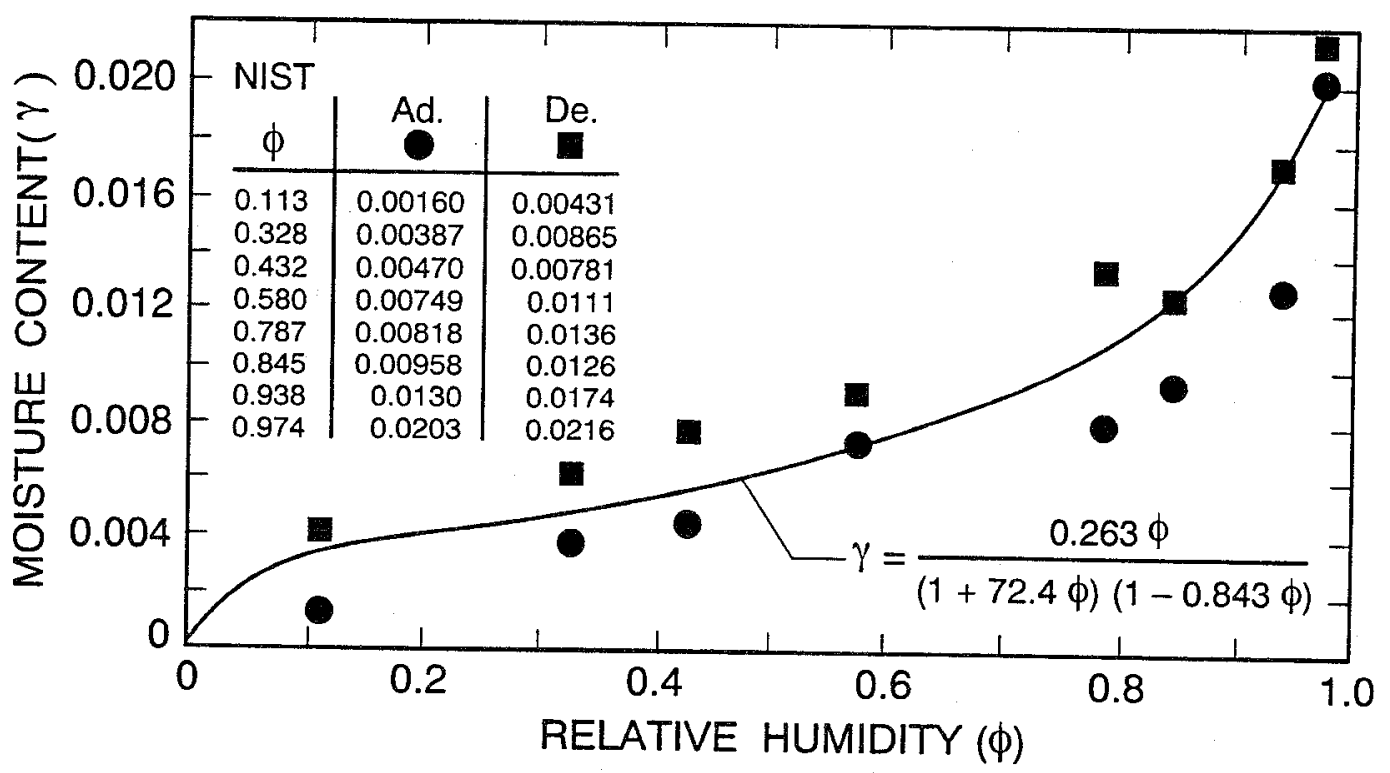

a. Sorption isotherm

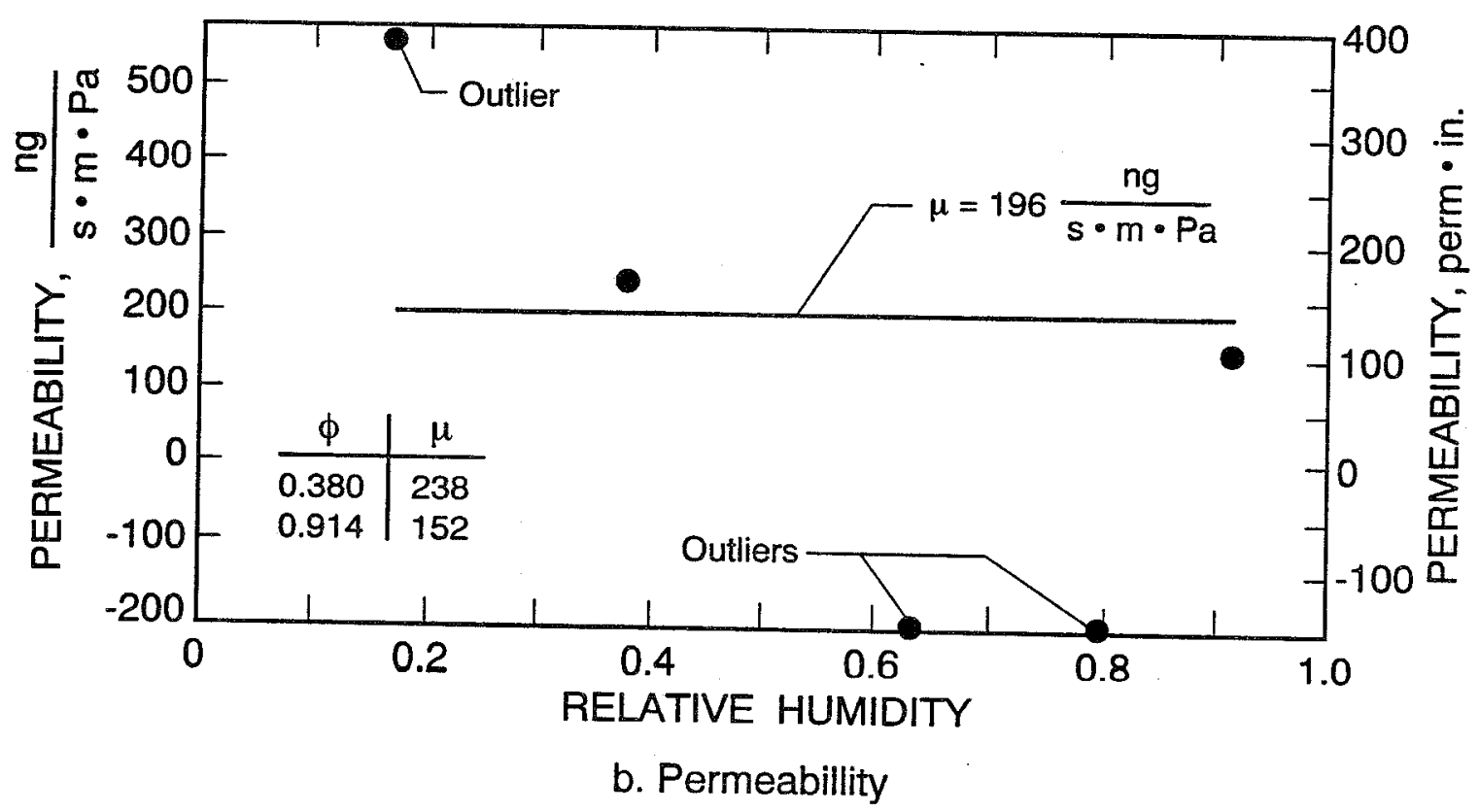

Fig. 9. Water-vapor properties of insulation for glass-fiber board. 
seemed reasonable and therefore were considered to represent the permeance of the material. The line shown in the plot is the average of these two measurements. The permeability measurements for glass-fiber insulation are considerably uncertain as will be shown in the next section.

The fact that the measured permeability is somewhat above the permeability of a stagnant air layer of $180 \mathrm{ng} / \mathrm{s} \mathrm{m} \cdot \mathrm{Pa}$ (120 perm in.) given by ASHRAE (1993) is probably an artifact of the measurement uncertainty.

The sorption isotherm of the facer for the glass-fiber board is given in Figure 10a and indicates that the facer is weakly hygroscopic. At an ambient relative humidity of $100 \%$, it's maximum sorption moisture content is only 0.019 or $1.9 \%$. The facer permeability measurements given in $10 \mathrm{~b}$ indicate that the permeance (permeability divided by thickness) ranges from $1.5 \mathrm{ng} / \mathrm{s} \mathrm{m}^{2} \cdot \mathrm{Pa}(0.027 \mathrm{perm})$ to $23 \mathrm{ng} / \mathrm{s} \cdot \mathrm{m}^{2} \cdot \mathrm{Pa}(0.4 \mathrm{perm})$, thereby indicating that the facer is an excellent vapor retarder.

\section{Comparison of Properties for Materials}

The sorption isotherms for the materials are compared in Figure 11a. The fiberboard, exterior grade plywood, and matt-glass facers for the polyisocyanurate insulation are strongly hygroscopic. These materials are capable of absorbing moisture in excess of $20 \%$ times their dry weight. The glass-fiber insulation and its facer are weakly hygroscopic because they are capable of absorbing less than $2.5 \%$ times their dry weight.

The permeance (permeability divided by thickness) of the materials are compared in Figure 11b. The permeance of the facer for the glass-fiber board is less than $57 \mathrm{ng} / \mathrm{s} \mathrm{m}^{2} \cdot \mathrm{Pa}(1.0 \mathrm{perm})$ over the entire humidity range, and therefore always performs as a vapor retarder. The plywood performs as a vapor retarder when the ambient relative humidity is less than $60 \%$. The permeance of the polyisocyanurate insulation is low, but it does not quite perform as a vapor retarder. The fiberboard, perlite board, and glass-fiber board insulation have a permeance larger than $1100 \mathrm{ng} / \mathrm{s} \mathrm{m}^{2} \cdot \mathrm{Pa}(20 \mathrm{perm})$ and are considered to be very permeable. 


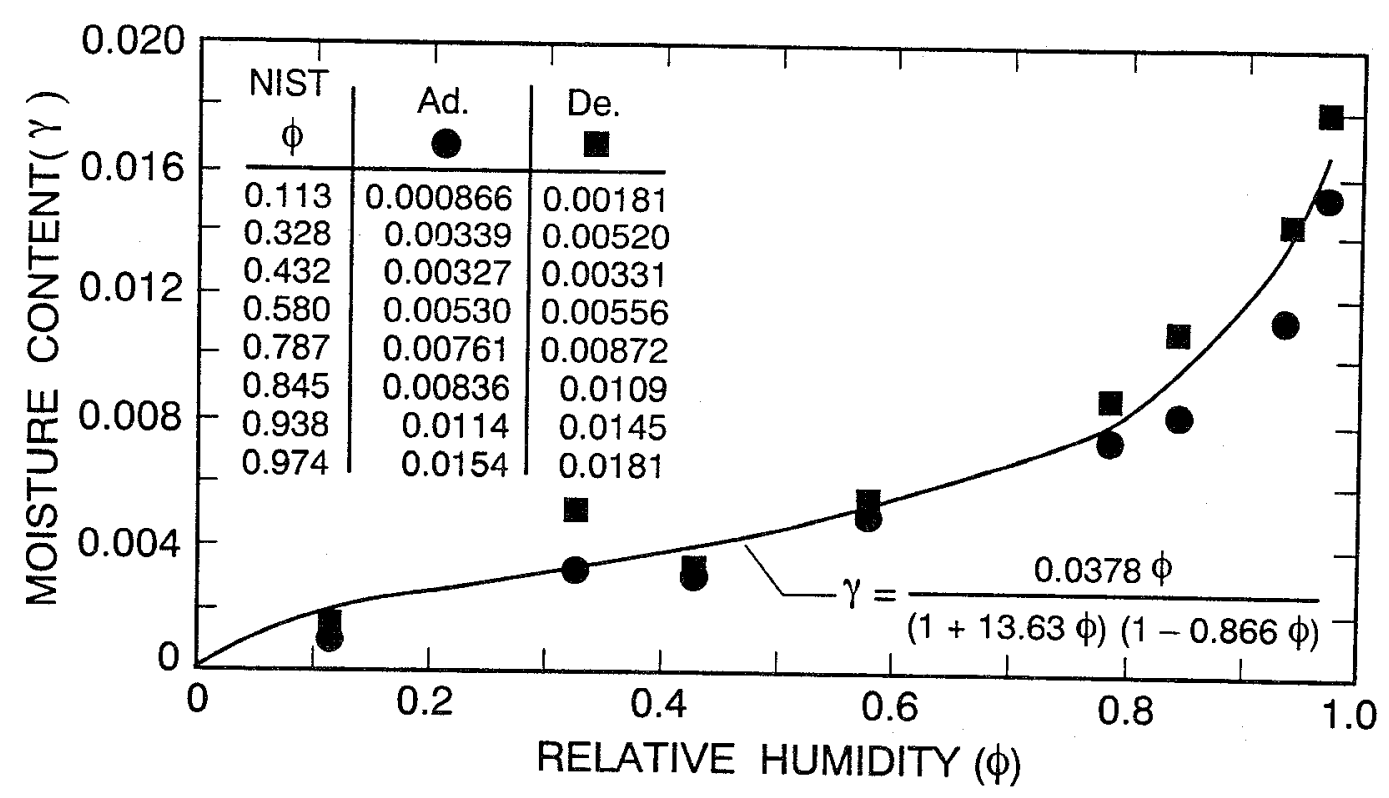

a. Sorption isotherm

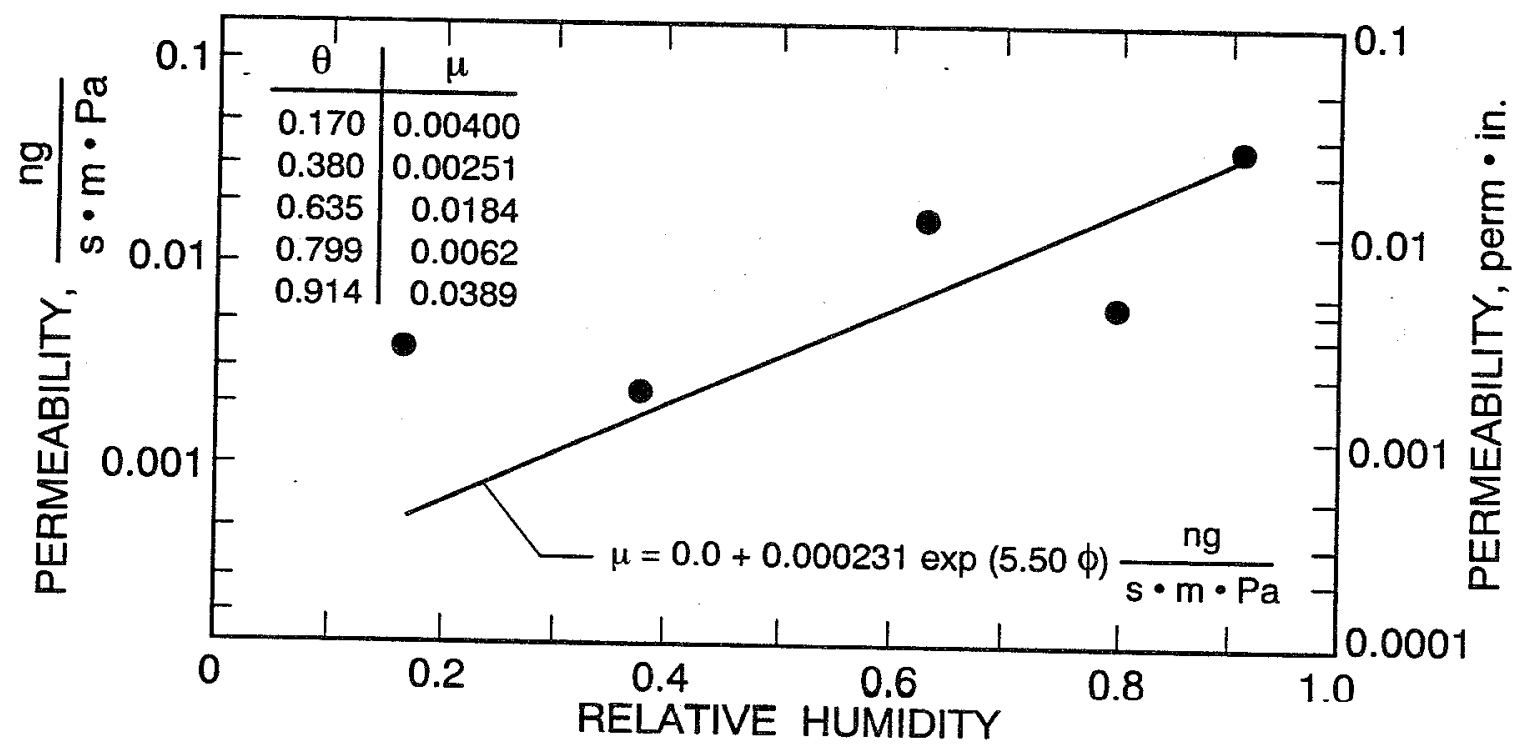

b. Permeabillity

Fig. 10. Water-vapor properties of facer for glass-fiber board. 


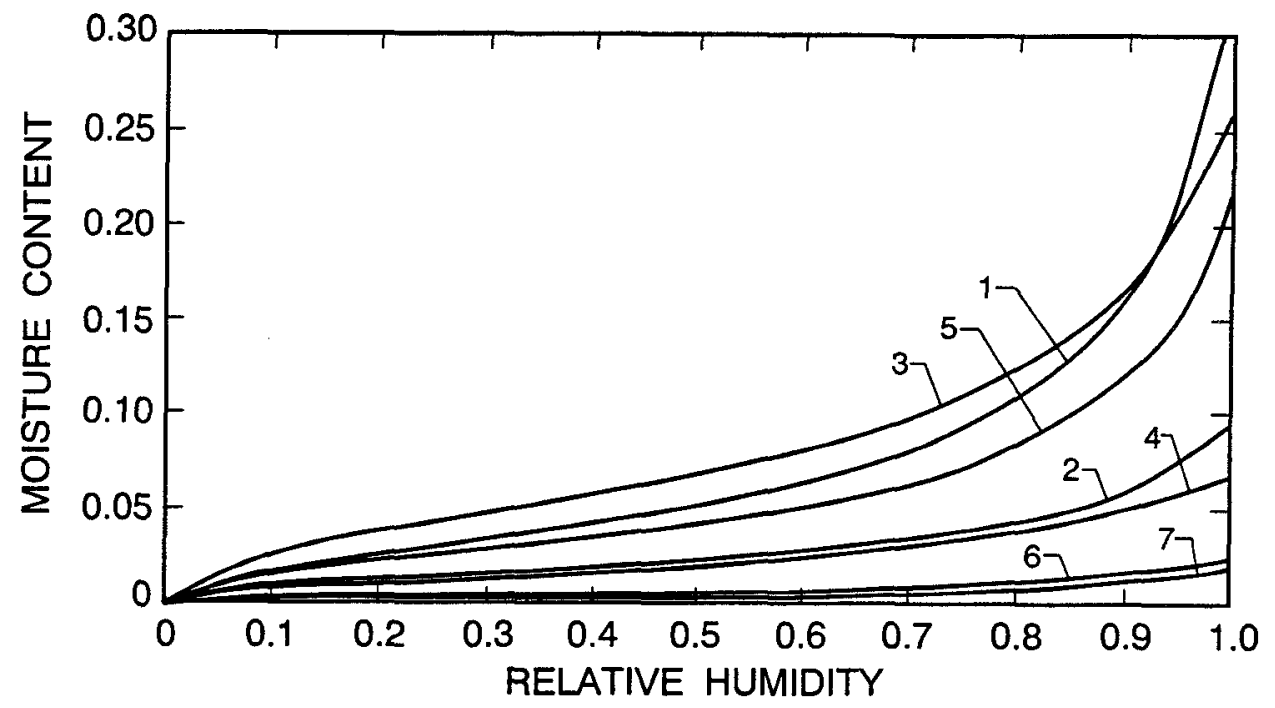

a. Sorption isotherm

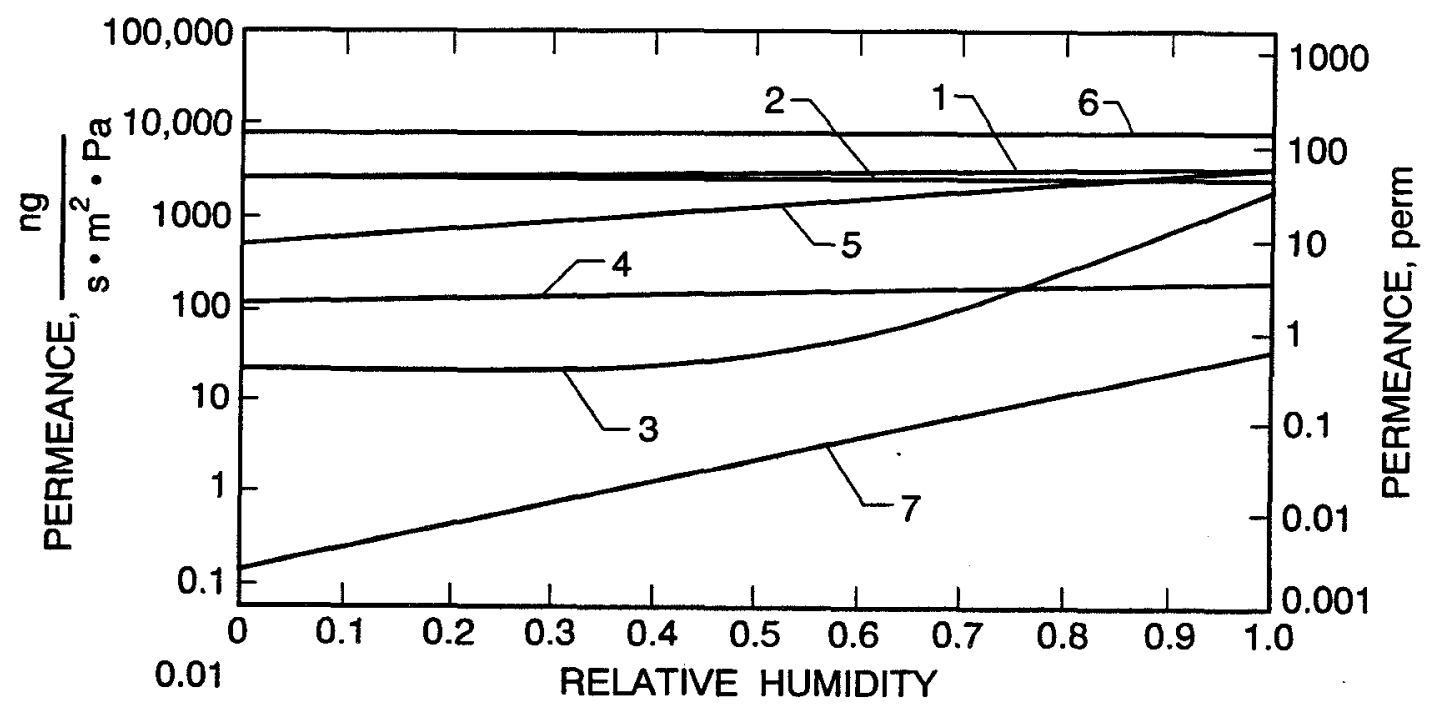

b. Permeabillity

\begin{tabular}{lr} 
Material & Index \\
\cline { 2 - 2 } Fiber Board & 1 \\
Perlite Board & 2 \\
Exterior-Grade Plywood & 3 \\
Polyisocyanuate Board \\
Insulation \\
$\quad$ Matt-Glass Facers & 4 \\
Glass-Fiber Board & 5 \\
$\quad$ Insulation & 6 \\
Facer & 7
\end{tabular}

Fig. 11. Comparison of water-vapor properties for roofing materials 


\section{UNCERTAINTY OF MEASUREMENTS}

From Kline and McClintock (1953), the uncertainty of a result $\left(\omega_{R}\right)$ based on a set of $n$ measurement variables $\left(\nu_{\mathrm{i}}\right)$ each having an uncertainty $\left(\omega_{\mathrm{i}}\right)$ may be determined by the equation:

$$
\omega_{\mathrm{R}}=\left[\left(\frac{\partial \mathrm{R}}{\partial v_{1}} \omega_{1}\right)^{2}+\left(\frac{\partial \mathrm{R}}{\partial v_{2}} \omega_{2}\right)^{2}+\ldots \ldots . .+\left(\frac{\partial \mathrm{R}}{\partial v_{\mathrm{n}}} \omega_{\mathrm{n}}\right)^{2}\right]^{0.5}
$$

where each of the partial derivatives are evaluated from a mathematical relation that relates the result to $\mathrm{n}$ measured variables.

\section{Sorption Isotherm Measurements}

For the sorption isotherm measurements, the only measured variable that can have a significant effect on the uncertainty of the sorption isotherm is the ambient relative humidity $(\phi)$ generated by the salt solutions. The uncertainty of weighing the specimens and determining their moisture content is comparatively smaller and is neglected in this analysis.

Differentiating Equation (5) with respect to $\phi$ and substituting the result into Equation (7) gives the following uncertainty expression for the moisture content:

$$
\frac{\omega_{\gamma}}{\gamma}=\left[1+\frac{a_{3} \phi}{1-a_{3} \phi}-\frac{a_{2} \phi}{1+a_{2} \phi}\right] \frac{\omega_{\phi}}{\phi}
$$

The uncertainties of the relative humidities generated by the salt solutions are given in Table 2 . The maximum uncertainty in the sorption isotherm measurements was found to be less than $\pm 1.5 \%$ moisture content.

\section{Permeability Measurements}

For the permeability measurements, measurement variables having a significant effect on the measurement uncertainty are: the water-vapor-transfer resistance of the air layers $\left(R_{f}\right)$, the relative humidity difference across the specimen $\left(\phi_{u}-\phi_{1}\right)$, and "effective" cross-sectional area of the specimen (A). The effective cross-sectional area of the specimen departs from the actual area of the specimen because some moisture is transferred around the specimen at its edges. The uncertainty associated with the other measurement variables of Equation 3 were believe to have considerably less effect and are neglected in the present analysis. For example, the thickness of the specimens were very accurately measured using a micrometer having a measurement uncertainty estimated to be $0.007 \mathrm{~mm}(0.0003 \mathrm{in})$, and its effect was neglected. 
Taking the partial derivatives of Equation (3) with respect to $R_{f},\left(\phi_{u}-\phi_{1}\right)$, and $A$ and substituting them into Equation 7 gives the following uncertainty expression for the permeability measurements:

$$
\begin{aligned}
\frac{\omega_{\mu}}{\mu}= & \left\{\left[\mathrm{MR}_{\mathrm{f}}\left(\frac{\omega_{\mathrm{R}_{f}}}{\mathrm{R}_{\mathrm{f}}}\right)\right]^{2}+\left[\left(1+\mathrm{MR}_{\mathrm{f}}\right)\left(\frac{\omega_{\Delta \phi}}{\phi_{\mathrm{u}}-\phi_{\mathrm{l}}}\right)\right]^{2}\right. \\
& \left.+\left[\left(1+\mathrm{MR} \mathrm{R}_{\mathrm{f}}\right)\left(\frac{\omega_{\mathrm{A}}}{\mathrm{A}}\right)\right]^{2}\right\}^{0.5}
\end{aligned}
$$

We estimated the uncertainties for the measurement variables to be the following: air layer resistance, $\omega_{R f} / R_{f}=0.1$ or $10 \%$; relative humidity difference, $\omega_{\Delta \phi} /\left(\phi_{\mathrm{u}}-\phi_{1}\right)=0.04$ or $4 \%$; and specimen area, $\omega_{A} / A=0.03$ or $3 \%$. Substituting these uncertainties into Equation 9 , we obtained the relationship between measurement uncertainty and specimen permeance given in Figure 12. When the specimen permeance is less than $57 \mathrm{ng} / \mathrm{s} \mathrm{m}^{2} \cdot \mathrm{Pa}(1 \mathrm{perm})$, the measurement uncertainty is about $\pm 5 \%$. When the permeance of the specimen is larger than $570 \mathrm{ng} / \mathrm{s} \mathrm{m}^{2} \cdot \mathrm{Pa}(10 \mathrm{perm})$, the uncertainty rises rapidly as the specimen permeance increases. The chart was terminated at $14,000 \mathrm{ng} / \mathrm{s} \mathrm{m}^{2} \cdot \mathrm{Pa}$ (240 perm) because it was believed that permeance measurements would not exceed this practical limit which corresponds to the permeance of $13.7 \mathrm{~mm}(0.5 \mathrm{in})$ thick stagnant air layer.

The permeance of the various roofing materials were evaluated at a relative humidity of $50 \%$, and their measurement uncertainties were calculated using Equation (9). The results are given

\begin{tabular}{|c|c|}
\hline \multicolumn{2}{|c|}{$\begin{array}{l}\text { Uncertainty of Permeability Measurements } \\
\text { Un }\end{array}$} \\
\hline Material & Uncertainty, \% \\
\hline Fiberboard & 25.2 \\
\hline Perlite Board & 22.5 \\
\hline Exterior-Grade Plywood & 5.1 \\
\hline $\begin{array}{l}\text { Polyisocyanurate Board } \\
\text { Insulation } \\
\text { Matt-Glass Facers } \\
\end{array}$ & $\begin{array}{c}5.6 \\
12.8\end{array}$ \\
\hline $\begin{array}{l}\text { Glass-Fiber Board } \\
\text { Insulation } \\
\text { Facer }\end{array}$ & $\begin{array}{c}67.0 \\
5.0\end{array}$ \\
\hline
\end{tabular}
in Table 5. 


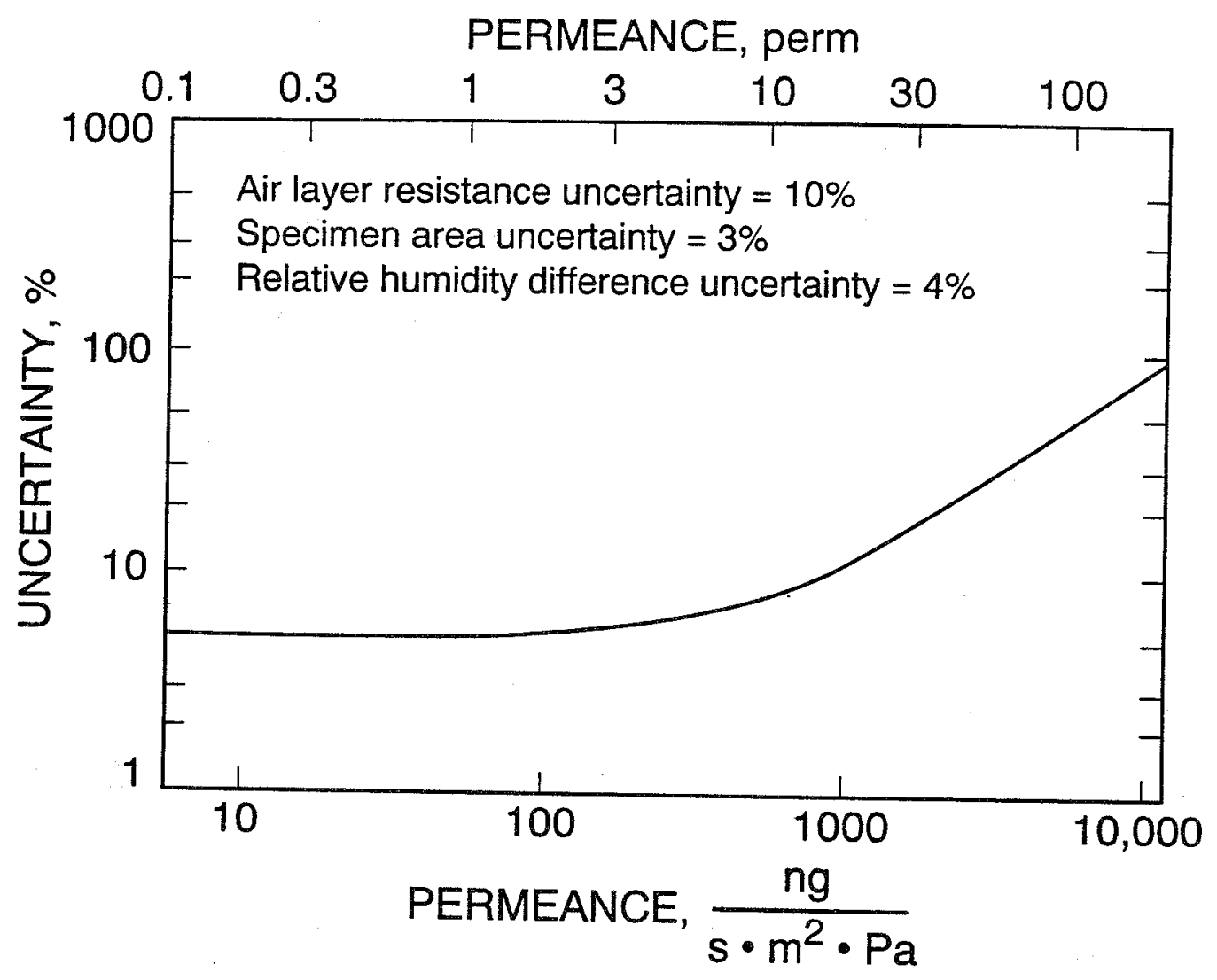

Fig. 12. Plot of uncertainty of permeability measurement versus specimen permeance. 


\section{SUMMARY AND CONCLUSIONS}

Two new measurement methods recently developed at the National Institute of Standards and Technology were used to measure the water-vapor sorption and permeability of five roofing materials, including their facers. The new measurement methods revealed that the moisture properties of building materials are often significantly dependent on average relative humidity. Standard measurement methods currently in use do not adequately account for the effect of relative humidity on moisture properties.

These measurements add to the material property data base for evolving models that predict the combined transfer of heat and moisture in building envelopes.

\section{ACKNOWLEDGMENTS}

The authors would like to thank the U.S. Department of Energy (through the Oak Ridge National Laboratory) for funding this research and Kim Whitter for preparing this report for publication. 


\section{NOMENCLATURE}

$\mathrm{a}_{\mathrm{n}} \quad=$ constants in sorption isotherm correlations $(\mathrm{n}=1,2$, and 3$)$

A $\quad=$ surface area, $\mathrm{m}^{2}\left(\mathrm{ft}^{2}\right)$

$A_{n} \quad=$ constants of permeability correlation $(n=1,2$, and 3 )

$\mathrm{f} \quad=$ sorption isotherm function

$\mathrm{G} \quad=$ specific moisture capacity, $\mathrm{kg}_{\mathrm{w}} / \mathrm{kg}_{\mathrm{d}}\left(\mathrm{lb}_{\mathrm{w}} / \mathrm{lb}_{\mathrm{d}}\right)$

$\mathrm{L} \quad=$ thickness, $\mathrm{m}(\mathrm{ft})$

$\mathrm{M} \quad=$ specimen permeance, $\mathrm{kg} / \mathrm{Pa} \mathrm{m}^{2}$ (perm)

$\mathrm{P}_{\mathrm{s}} \quad$ = saturated water-vapor pressure, $\mathrm{Pa}$ (inHg)

$\mathrm{R}_{\mathrm{f}} \quad=$ air layer water-vapor transfer resistance, $\mathrm{Pa} \mathrm{s} \mathrm{m}^{2} / \mathrm{kg}(1 / \mathrm{perm})$

$\mathrm{t} \quad=$ time, $\mathrm{s}(\mathrm{h})$

$\mathrm{T}=$ temperature, ${ }^{\circ} \mathrm{C}\left({ }^{\circ} \mathrm{F}\right)$

WVT $=$ water-vapor transfer rate, $\mathrm{kg} / \mathrm{s}(\mathrm{lb} / \mathrm{h})$

$\mathrm{x} \quad=$ distance, $\mathrm{m}(\mathrm{ft})$

$\Delta \quad=$ difference

$\gamma \quad=$ moisture content, dry basis, $\mathrm{kg}_{\mathrm{w}} / \mathrm{kg}_{\mathrm{d}}\left(\mathrm{lb}_{\mathrm{w}} / \mathrm{lb}_{\mathrm{d}}\right)$

$\mu \quad=$ permeability, $\mathrm{kg} / \mathrm{Pa} \cdot \mathrm{m}$ (perm in.)

$\phi \quad=$ relative humidity

$\rho \quad=$ dry density, $\mathrm{kg} / \mathrm{m}^{3}\left(\mathrm{lb} / \mathrm{ft}^{3}\right)$

$v \quad=$ measurement variable

$\omega \quad=$ uncertainty

\section{Subscripts}

$\begin{array}{ll}\mathrm{l} & =\text { lower } \\ \mathrm{R} & =\text { result } \\ \mathrm{u} & =\text { upper } \\ \mathrm{w} & =\text { wet property }\end{array}$




\section{REFERENCES}

Anderson, R.G. 1985. "Dry Range and Wet Range Moisture Content of Roofing Materials as Found in Existing Roofs." Proceedings of the Second International Symposium on Roofing Technology, NRCA, Rosemount, Ill., September, 1985.

ASHRAE. 1993. ASHRAE Handbook - Fundamentals, Chapter 22. Atlanta: American Society of Heating, Refrigerating and Air-Conditioning Engineers, Inc.

ASTM. 1994. Standard Test Methods for Water Vapor Transmission of Materials, ASTM E9680. Annual Book of ASTM Standards, Section 4, Vol. 4, pp. 634-641.

Baxter, G.P. and Starkweather, H.W. 1916. "The Efficiency of Calcium Chloride, Sodium Hydroxide, and Potassium Hydroxide as Drying Agents. " Journal of the American chemical Society 38(2): 2038-2041.

Burch, D.M.; Thomas, W.C.; and Fanney, A.H. 1992. "Water Vapor Permeability Measurements of Common Building Materials." ASHRAE Transactions, Vol. 98, Part 2.

Fanney, A.H.; Thomas, W.C.; Burch, D.M.; and Mathena, Jr. L.R. 1991. "Measurements of Moisture Diffusion in Building Materials." ASHRAE Transactions, 97(2).

Galbraith, G.H. and McLean, R.C. 1990. "Interstitial Condensation and the Vapor Permeability of Building Materials." Energy and Buildings, Vol. 14, pp. 193-196.

Greenspan, L. 1977. "Humidity Fixed Points of Binary Saturated Aqueous Solutions." National Bureau of Standards. Journal of Research, 81A: 89-96.

Hedlin, C.P. 1988. "Heat Flow Through a Roof Having Moisture Contents Between 0 and 1\% by Volume in summer." ASHRAE Transactions, Part 2, pp. 1579-1594.

Kline, S.J. and McClintock, F.A. 1953. "Describing Uncertainties in Single-Sample Experiments." Mechanical Engineering, January, pp. 3-8.

Knab, L.; Mathey, R.; and Jenkins, D. 1981. "Laboratory Evaluation of Nondestructive Methods to Measure Moisture in Built-Up Roof Systems. " Building Science Series 131, National Institute of Standards and Technology, January.

Nguyen, T.; Byrd, E.; Zarr, R.R.; Stutzman, P.; and Seiler, J. 1991. "Effects of Environmental Exposure on the Properties of Polyisocyanurate Insulation Foam: Material Properties." Proceedings of 2nd International Workshop on Long-Term Thermal Performance of Cellular Plastics at Niagara-on-the-Lake, Ontario, June. 
Richards, R.F.; Burch, D.M.; and Thomas, W.C. 1992. "Water Vapor Sorption Measurements of Common Building Materials." ASHRAE Transactions, Vol. 98, Part 2.

Rode (formerly Pedersen), C. 1990. "Combined Heat and Moisture Transfer in Building Constructions, Thermal Insulation Laboratory, Technical University of Denmark, Lynby, September.

Simpson, W.T. 1971. "Equilibrium Moisture Content Prediction for Wood." Forest Products Journal, Vol. 21, No. 5, pp. 48-49.

Tobiasson, W. Greatorex, A., and Van Pelt, D. 1991. "New Wetting Curves for Common Insulations." International Symposium on Roofing Technology, NIST/NRCA, National Roofing Contractors Association.

Tveit, A. 1966. "Measurements of Moisture Sorption and Moisture Permeability of Porous Materials." Report UDC 532.685. Norwegian Building Research Institute, Oslo. 